
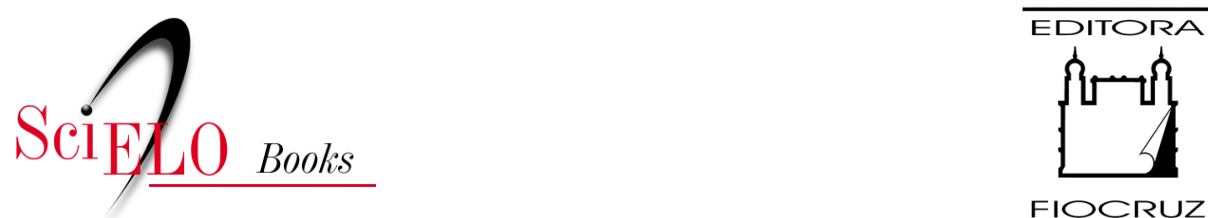

FIOCRUZ

\title{
2. O Seguro Social de Doença (GKV)
}

\author{
Lígia Giovanella
}

\section{SciELO Books / SciELO Livros / SciELO Libros}

GIOVANELLA, L. O Seguro Social de Doença (GKV). In:

Solidariedade ou Competição? Políticas e sistema de atenção à saúde na Alemanha [online]. Rio de Janeiro: Editora FIOCRUZ, 2001, pp. 53-95. ISBN: 978-65-5708-097-9. http://doi.org/10.7476/9786557080979.0005.

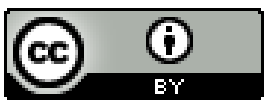

All the contents of this work, except where otherwise noted, is licensed under a Creative Commons Attribution 4.0 International license.

Todo o conteúdo deste trabalho, exceto quando houver ressalva, é publicado sob a licença Creative Commons Atribição 4.0.

Todo el contenido de esta obra, excepto donde se indique lo contrario, está bajo licencia de la licencia Creative Commons Reconocimento 4.0. 


\section{Seguro Social de 2 Doença $(G K V)$}

A proteção social à saúde na Alemanha, organizada segundo o modelo de seguro social, é garantida mediante um sistema de contratação compulsória e tem como sua instituição central o Gesetzliche Krankenversicherung (GKV), literalmente, seguro de doença legal. A execução do asseguramento à doença não é de responsabilidade direta da administração estatal. É transferida para instituições de direito público de administração autônoma, as Caixas de Doença, (Krankenkassen), que são geridas por representações dos trabalhadores e empregadores.

O Gesetzliche Krankenversicherung (GKV) faz parte de amplo sistema de proteção social, com o qual compartilha princípios e características básicas. Relacionadas à opcracionalização de seus princípios constitutivos de solidariedade, subsidiariedade e equivalência, as características básicas do seguro-doença são: 1) administração autônoma das instituições de seguro social (Selbstverwaltunsgprinzip); 2) pluralidade e integração do sistema (gegliederte Krankenversicherung), composto por Caixas organizadas segundo diversos critérios como profissão, ramo de produção, região ou empresa; 3) distribuição de benefícios em açōes de saúde e não em espécie; 4) financiamento mediante contribuições paritárias de empregadores e trabalhadores (BMAS, 1994). ${ }^{40}$

Tais especificidades derivam do modo de conformação do Seguro Social de Doença em sua gênese e vigoram, em termos gerais, desde sua instituição em fins do século passado. O princípio de autonomia administrativa é definido como liberdade de auto-regulaçāo e execuçāo de tarefas públicas sob vigilância estatal através dos círculos sociais interessados e seus representantes (Bogs, 1976). Trata-

10 Neste estudo consideram-se 'características básicas' a administração autônoma, a pluralidade do sistema e a distribuição de benefícios em ações (Sachleistungsprinzip), ainda que sejam referidos como 'princípios' nas publicações oficiais, para diferenciá-los dos 'princípios instituintes' do seguro social - solidariedade, subsidiariedade e equivalência. 
se de autonomia mediada pelo Estado, cujo âmbito de ação e tarefa são definidos por legislação. À época da criação do Seguro Social de Doença, esta opção deveuse à existência anterior de organizações cooperativas dos trabalhadores, que foram colocadas sob promoção e controle estatais.

Outra das características básicas do sistema é a pluralidade das organizações responsáveis pelo asseguramento. $\mathrm{O}$ modelo conservador de seguro social bismarckiano reproduziu as desigualdades sociais prévias no asseguramento dos riscos sociais, o que resultou em multiplicidade e diversidade de Caixas com adscriçāo de clientelas diferenciadas conforme a inserção no processo produtivo.

Conquanto o sistema seja organizado com base em modelo de seguro, pois o direito de acesso depende da contribuição prévia, não vige o princípio de restituição de despesas. As açōes médico-sanitárias sāo colocadas à disposição para serem utilizadas de forma gratuita e direta (Sachleistungsprinzip): literalmente, princípio de pagamento em produtos in natura. A prestação em ações de saúde garante a assistência ao doente independente de sua situação financeira, uma vez que não implica desembolso direto do paciente no ato da utilização. Para a efetivação deste princípio, as Caixas fecham contratos com hospitais e farmácias, credenciam médicos, dentistas e outros profissionais, ao passo que os prestadores contratados obrigam-se a prestar atençāo aos segurados com ônus para as Caixas. ${ }^{41}$

\section{Cobertura Dopulacional e Círculo de Beneficiários}

A proteção social à saúde na Alemanha é inclusiva e extensiva. A grande maioria da população é coberta pelo Seguro Social de Doença (Gesetzliche Krankenversicherung - GKV) e tem acesso à ampla rede de assistência médicosanitária em seus diversos níveis de complexidade. Englobando atualmente cerca de $90 \%$ da população residente, o GKV é a mais importante forma de proteção à saúde e à maternidade na Alemanha. Em paralelo à cobertura crescente do GKV desde a sua criação, as outras formas de asseguramento (seguro privado, ajuda beneficente, previdência para vítimas da guerra, previdência da polícia e forças armadas, além da atenção médica no âmbito da assistência social) tiveram sua clientela reduzida.

11 Segundo o princípio de restituição de gastos vigente nos seguros privados, o segurado paga a sua conta ao médico, hospital ou farmácia e solicita restituição à seguradora. Desse modo, o seguro privado não estabelece vínculo com os prestadores nem tem responsabilidade quanto a remunerá-los ou mesmo à possibilidade de negociar preços. A relação do seguro privado é com o segurado contratante, o qual tem seus gastos restituídos conforme os termos estipulados no contrato. 


\section{População coberta}

Em 1995, como exposto na tabela abaixo, $88,46 \%$ da população era assegurada pelo $\mathrm{GKV}$, cerca de $9 \%$ eram assegurados privadamente e apenas $0,13 \%$ não dispunha de proteção na Alemanha como um todo. ${ }^{12}$ Supōe-sc que esta última parcela seja constituída pelos mais ricos, já que os menos favorecidos com domicílio fixo estão incluídos nas estatísticas e têm sua proteção à saúde garantida pela assistência social, alcançando proporçāo menor do que $2 \%$ da populaçāo total. ${ }^{43}$

Tabela 1 - Proteção à saúde. Alemanha - 1995

\begin{tabular}{|c|c|c|c|c|c|c|}
\hline \multirow[t]{2}{*}{ Forma de proteção } & \multicolumn{2}{|c|}{ Alemanha } & \multicolumn{2}{|c|}{ Ocidental } & \multicolumn{2}{|c|}{ Oriental } \\
\hline & Pop.* & $\%$ & Pop. & $\%$ & Pop. & $\%$ \\
\hline GKV: scguro social & 72.156 & 88,46 & 57.211 & 86,60 & 14.942 & 96,36 \\
\hline Scguro privado & 7.380 & 9,05 & 7.049 & 10,67 & 333 & 2,15 \\
\hline Prev. Polícia/Forças Armadas & 605 & 0,74 & 482 & 0,73 & 123 & 0,79 \\
\hline Assistência social c outros ** & 1.324 & 1,62 & 1.229 & 1,86 & 95 & 0,61 \\
\hline Sem proteção & 105 & 0,13 & 93 & 0,14 & 13 & 0,08 \\
\hline População total & 81.570 & 100,00 & 66.064 & 100,00 & 15.506 & 100,00 \\
\hline
\end{tabular}

* População cm milhares. ** Inclusive aposentados/auxílio de guerra.

Fonte: StBA, 1995b.

Pessoas carentes têm acesso à atenção à saúde gratuita por meio da assistência social, porém, arcam com todos os ônus em ser beneficiários desse tipo de assistência: preencher requisitos de elegibilidade, comprovar carência, solicitar autorização para cada consulta, submeter-se ao humor do burocrata e, ainda, ser estigmatizado. Quando o asseguramento voluntário no GKV é possível, conforme regras descritas na próxima seção, o órgão responsável pela assistência social dos municípios paga a contribuição; deste modo, a maioria dos beneficiários da assistência social é segurada pelo GKV.

A região da ex-Alemanha Oriental diferencia-se da Ocidental por incluir quase toda a sua população no Seguro Social de Doença. Em 1996, 96\% da população da regiāo oriental era segurada do GKV. Assim, após a unificaçāo, mantevese a cobertura quase universal na região oriental, similar àquela do antigo Estado

42 Após 1991, sempre que a regiâo da Alemanha não estiver especificada neste trabalho, a observação ou os dados referem-se à Alemantsa unificada.

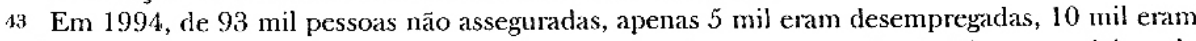
assalariadas e 76 mil eram não economicamente ativas, o que pode significar que viviam de rendas. 
socialista, mesmo que o sistema ocidental tenha sido diretamente estendido à região oriental, substituindo a forma anterior de proteção. A proteção social socialista também tinha seus fundamentos em seguro social relacionado à ocupação, sendo, contudo, único para todos os riscos sociais e complementado por seguro estatal para outros grupos populacionais não ocupados.

A República Democrática Alemã (Deutsche Demokratische Republik DDR) foi o mais rico e produtivo país do Comecon (Council for Mutual Economic Assistance), organização econômica do Estados do Leste, c dispunha de amplo sistema de proteção social, constituído por um mix de seguro social e seguridade social.

Ao contrário dos outros paíscs socialistas do leste europeu que mantiveram seu direito e reformaram gradualmente suas constituiçōes, o contrato de unificação da Alemanha Oriental definiu a sua autodissolução. Isso porque, segundo Offe (1993), a RDA constituiu-se em um Estado apenas em nível econômico, mas não em uma nação. O processo de unificação significou, para a Alemanha Oriental, a sua extinção enquanto Estado. Em 1ํ de julho de 1990 passou a viger, em seu território, a Constituição da República Federal da Alemanha, c o sistema de proteção em seus diversos ramos, inclusive o GKV, foi estendido para sua populaçāo. ${ }^{4}$

Na região ocidental, a cobertura pelo GKV é igualmente alta, atingindo $87 \%$ da população; todavia, é mais baixa do que na região oriental. A proporção de pessoas com seguro privado nessa regiāo é mais elevada do que na região oriental, correspondendo a $11 \%$ da população, o que condiz com sua situação econômica mais vantajosa: maior PIB per capita e salários mais altos. Como veremos a seguir, empregados que recebem salários acima de determinado patamar não são compulsoriamente obrigados a filiar-se ao seguro social.

\section{Evolução da proteção à saúde nas últimas décadas}

O Scguro Social de Doença aumentou progressivamente a sua cobertura por conta de um processo contínuo de inclusão. Acompanhando a série histórica da região ocidental ${ }^{45}$ na tabela a seguir, pode-se observar a evolução da proteção ao

4 Para outras informaçōes sobre o sistema de proteção na DDR, ver Giovanelta, 1998. O trabalho refere-se especificamentc à proteção à saúde da República Federal da Alemanha (Bundesrepublik Deutschland-BRD). Não são analisadas especificidades do sistema da exRepública Democrática Alemā (DDR-Deutsche Demokratische Republik). A unificação signilicou não apenas o desmantelamento do regime socialista e de suas formas de produção. mas também de sua proteção social e formas de assistência à saúde, estendendo-se o sistema ocidental à região oriental e sendo definidas apenas algumas regras de transição.

4.5 Em decontencia da agregaçāo da Alemanha Oriental em 1989, as séties históricas anteriores aos anos 90 scrão sempre apresentadas apenas para a região ocidental, a fim de possibilitar comparação. 
risco de adoecer nas últimas décadas. Na Alemanha ocidental, desde 1970, o nível de proteção pelo Seguro Social de Doença, GKV, mantém-se próximo aos 90\% da população residente, mostrando pequenas variaçōes. O número de segurados do GKV na população total atingiu seu ponto mais alto na década de 80. De lá para cá, comparando-se a situação de 1995 com 1980, a proporção de segurados pelo GKV na região ocidental diminuiu em 3,7 pontos percentuais, embora tenha elevado o número absoluto de segurados.

Tabela 2 - Proteção à̀ saúde. Alemanha (Região Ocidental) - 1970-1995*

\begin{tabular}{l|rr|rr|rr|rr}
\hline \multirow{2}{*}{ Forma de Proteção } & \multicolumn{2}{|c|}{1970} & \multicolumn{2}{|c|}{1980} & \multicolumn{2}{c|}{1990} & \multicolumn{2}{c}{1995} \\
\cline { 2 - 9 } & Pop.* & $\%$ & Pop. & $\%$ & Pop. & $\%$ & Pop. & $\%$ \\
\hline GKV - Scguro Social & 53.531 & 87,87 & 55.565 & 90.33 & 54.361 & 86,20 & 57.211 & 86,60 \\
Seguro privado & 5.696 & 9,35 & 4.611 & 7,50 & 6.935 & 11,00 & 7.049 & 10,67 \\
Prcv. Polícia/F. Arm. & 1.013 & 1,66 & 6.55 & 1,06 & 695 & 1,10 & 482 & 0,73 \\
Assist. social ** & $* * *$ & $* * *$ & 549 & 0,89 & 974 & 1,54 & 1.229 & 1,86 \\
Sem proteção & 684 & 1,12 & 137 & 0,22 & 97 & 0,15 & 93 & 0,14 \\
População total & 60.924 & 100,00 & 61.516 & 100,00 & 63.062 & 100,00 & 66.064 & 100,00 \\
\hline
\end{tabular}

*População cm milhares. **Inclusive aposentados de guerra c beneficiários de outras formas de compensação por danos na guerra. ***Os dados estão agrupados na categoria anterior.

Fonte: SVR, 1994 T. 300; StBA, 1980, 1990, 1995b. (cálculos próprios)

A proporçāo de segurados privados tem permanecido cstável durante os anos de 1990. Nas décadas antcriorcs, no entanto, apresentou oscilaçōes. A participação dos segurados privados diminuiu nos anos 70 , observando-se menor número de segurados privados em 1980, mas voltou a aumentar nos anos 80 , estabilizando-se em cerca de $11 \%$ da população na primeira metade da década de 1990.

Conquanto a variação percentual seja baixa, entre 1980 e 1995 o crescimento do número absoluto de scgurados privados é expressivo: $60 \%$. Sc cotejado com 1970, o aumento fica em 20\%, em razão da variação no período. Em 1989, ano da entrada em vigor da Lei da Reforma da Saúde, o número de segurados privados aumentou, pois a lei dificultou o ingresso de aposentados e autônomos no Seguro Social de Doença e liberou os operários que percebiam acima de certo nível de renda da obrigatoriedade de asseguramento. Alćm disso, tarifa básica para o seguro privado foi regulamentada. 
Chama também a atenção o aumento da população que precisa recorrer à assistência social para garantir atenção à saúde. A despeito de a participação deste grupo ficar, em termos relativos, abaixo de $2 \%$ em 1995 , o número de pessoas que dispõe apenas da assistência social para a proteção à saúde dobrou entre 1980 e 1995, passando de 550 mil para 1,2 milhōes. Paralela a esta evolução, a proporção de pessoas desprotegidas diminuiu tanto em termos numéricos quanto em termos relativos, correspondendo a apenas $0,14 \%$ da população (93 mil pessoas) em $1995 .{ }^{46}$

\section{Proteção à saúde conforme a participação na economia}

Apesar de a proteção à saúde na Alemanha ser conformada a um modelo de seguro social em que esse direito está condicionado à integração ao mercado de trabalho, a participaçāo ou não no mercado de trabalho tem pouca influência no nível de asseguramento pelo GKV. Para as pessoas que trabalham, essa proteção é mesmo levemente mais baixa do que a da população em geral, o que não significa que estejam desprotegidas. Uma parcela maior da população ocupada é assegurada privadamente, pois os trabalhadores que recebem salários elevados acima de certo limite, assim como os funcionários públicos, são desobrigados da participação compulsória no Seguro Social de Doença.

Esta perda de importância da participação no mercado de trabalho para garantia da proteção reforça a afirmação das características de universalidade que o sistema de seguro social adquiriu em sua evolução. Ao mesmo tempo, o alto nível de proteção, em inclusão e extensão, contribui para a elevada accitabilidade do seguro social, inviabilizando propostas de constituição de um sistema de proteção desvinculado do trabalho.

Uma cobertura pelo GKV em nível similar não significa, porém, que a situação de proteção seja idêntica para as populações ocupada, desempregada e não economicamente ativa. Considerada a distribuição da população alemã conforme sua participação na economia, a situação dos desempregados ${ }^{47}$ se destaca. Estes são protegidos pelo seguro social em proporção mais elevada do que o conjunto da população ou do que a população ocupada, mas é também entre estes que se concentra a maior proporção daqueles que recorrem à assistência social.

16. Além da inclusão, isto pode indicar que, mesmo pessoas de altas posses tenham passado a assegurar-se com mais freqüência, em razão dos preços cada vez mais altos da atenção médica e da introdução de procedimentos cada vez mais caros.

47 Em 1995, na Alemanha como um todo, 7,6\% dos desempregados tinham proteção à saúde apenas via assistência social e poucos eram os que se asseguravam voluntariamente ou arcavam com seguro privado. Esta situação era bem diferenciada daquela da população em geral, em que apenas $1,6 \%$ das pessoas garantiam atenção médico-sanitária pela assistência social. 
A cvolução da proteção à saúde conforme a participação no mercado de trabalho segue o padrão daquela apresentada para a população como um todo. No que concerne à região ocidental, pode-se observar, na tabcla a seguir, a progressão recente da proteção à saúde (de 1980 a 1995) de acordo com a posição no mercado de trabalho. Nesse período, ocorreu leve diminuição da cobertura do GKV, que foi mais acentuada entre a população ocupada, passando de $90 \%$ para $85 \%$, diferencial compensado pela maior participação no seguro privado. $\mathrm{O}$ número de pessoas ocupadas que são asseguradas privadamente cresceu em cerca de $50 \%$, passando esta participação de $7,6 \%$ para $13 \%$, tendo sido agregado um contingente de 3,7 milhões de pessoas.

Entre os desempregados c os não cconomicamente ativos, chama a atenção o aumento do grupo cuja protecão à saúde é garantida por outras formas de proteção, em especial. a assistência social. ${ }^{18}$

Tabela 3 - Distribuição da população conforme participação na economia e forma de proteção à saúde. Região Ocidental - 1980 e 1995

\begin{tabular}{l|r|r|r|r|r|r|r|r}
\hline \multirow{2}{*}{$\begin{array}{l}\text { Formas de } \\
\text { proteção }\end{array}$} & \multicolumn{2}{|c|}{ Ocupados } & \multicolumn{2}{c|}{ Descmpreg. } & \multicolumn{2}{c|}{ Não ccon. ativ. } & \multicolumn{2}{c}{ Total. } \\
\cline { 2 - 9 } & 1980 & 1995 & 1980 & 1995 & 1980 & 1995 & 1980 & 1995 \\
\hline GKV & 89,89 & 85,23 & 89,55 & 88,03 & 90,69 & 87,66 & 90,33 & 86,60 \\
Scguro privado & 7,59 & 12,94 & 2,34 & 1,98 & 7,53 & 9,41 & 7,50 & 10.67 \\
Outros* & 2,45 & 1,77 & 7,18 & 9,77 & 1,44 & 2,73 & 1.95 & 2,60 \\
Não segurados & 0,06 & 0,06 & 0,91 & 0,22 & 0,33 & 0,20 & 0,22 & 0,14 \\
\hline Tơtal & 100,00 & 100,00 & 100,00 & 100,00 & 100,00 & 100.00 & 100,00 & 100.00 \\
\hline
\end{tabular}

*Bencficiários da assistência social, segurados de gucrra $\mathrm{c}$ outras formas de compensação de danos de gucrra

Fonte: StBA, 1980 c 1995. Os dados referem-sc aos resultados dos microcensos de abril de 1980 c 1995.

\section{Regras de inclusão}

Restrito ao operariado industrial em sua origem, o Seguro Social de Doença teve a cobertura ampliada de modo progressivo em seus mais de cem anos de existência, passando a englobar a grande maioria dos trabalhadores assalariados operários e empregados -, assim como parte dos trabalhadores autônomos e dos

is O número e proporção de desempregados aumenton muito no período. $A$ taxa de desemprego passou de cerca de $2,8 \%$ da população economicamente ativa. em 1980, para 8,4\% em 199:. 
proprietários rurais. Até certo limite de renda, o seguro é compulsório para a população ocupada e exclui trabalhadores em situação de ocupação mínima. Os integrantes do sistema são diferenciados scgundo uma tipologia de scgurados: obrigatórios, aposentados, voluntários e familiares dependentes.

\section{Segurados obrigatórios}

Segurados obrigatórios são aqueles inscritos compulsoriamente pela força da lei. Entre os segurados obrigatórios contam-se os trabalhadores ativos e os aposentados.

Por muito tempo, o asseguramento compulsório dos trabalhadorcs foi regulamentado de forma distinta para empregados e operários, conferindo-lhes status diferenciado. Enquanto todos os operários (com salário semanal, por hora trabalhada $(L o h n)$ ) eram obrigados a assegurar-se, os empregados (que recebem ordenado mensal ( $G e h a l t)$ ) o eram apenas até certo limite de renda. Somente em 1988, com a Lei da Reforma da Saúde, os dois grupos adquiriram o mesmo status. A partir de então, o asseguramento tornou-se obrigatório para trabalhadores empregados e operários - cujos rendimentos do trabalho assalariado regular não ultrapassavam $75 \%$ do limite máximo para a contribuição da previdência social (seguro-aposentadoria). Isto significou que uma parcela dos operários melhor remuncrados foi desobrigada do asseguramento compulsório.

Em 1997, o salário mensal máximo limite para desconto de contribuição e para obrigatoriedade de participação no Seguro Social de Doença na regiāo ocidental era de 6.150 marcos (US $\$ 4$ mil) e, na região oriental, 5.325 marcos (US $\$$ 3,5 mil). ${ }^{49}$

Além dos trabalhadores empregados, grupos não empregados também são assegurados compulsoriamente. Aposentados da previdência social, desempregados que recebem seguro-desemprego, cstudantes universitários, pessoas em formação ou treinamento profissional, aprendizes, participantes de medidas de promoção ou reabilitação para o trabalho e deficientes que exercem atividades em instituições especiais são também membros obrigatórios do Seguro Social de Doença (SGB,1993). Para alguns destes grupos, regras mais detalhadas especificam - restringem ou liberam - sua participação.

$\mathrm{O}$ asseguramento obrigatório dos aposentados depende de sua participação anterior no sistema. Somcntc são assegurados os que comprovem ter sido segurados obrigatórios durante, no mínimo, $50 \%$ de seu tempo de trabalho. $\mathrm{O}$

49 O estabelecimento de um limite máximo de renda para o asseguramento nos esquemas compulsórios estaria de acordo com o princípio da subsidiariedade. Não decorreu, porém, apenas destc princípio, mas também da exigência dos próprios médicos, que queriam garantir suas rendas provenientes da clínica privada. 
objetivo desta regra seria garantir o direito de participaçāo apenas aos aposentados que contribuíram para o sistema durante a vida ativa, melhor remunerada, e não optaram pelo seguro privado, por vezes, mais em conta. Isto é, deram sua parcela de contribuição solidária. Como foi visto anteriormente, as contribuições dos aposentados não cobrem seus gastos.

Cinqüenta por cento das contribuiçōes dos aposentados são pagas pela previdência social e equivalem a taxas médias nacionais legisladas, as quais nem sempre correspondem às necessidades financeiras de determinada Caixa. Por este motivo, existe, entre as Caixas, uma compensação financeira relativa aos diferenciais da proporção de aposentados. Ainda que os aposentados continuem a ser filiados à mesma Caixa à qual eram segurados durante a vida ativa, constituem o chamado Seguro-Doença dos Aposentados (Krankenversicherung der Rentner) por conta das particularidades de suas contribuições.

Os desempregados são assegurados enquanto recebem seguro-desemprego ou auxílio-desemprego. Caso permaneçam mais tempo desempregados do que a duração destes auxílios, poderão contribuir voluntariamente. A assistência social passa a pagar suas contribuiçōes se comprovarem a necessidade, e os desempregados permanecem membros do sistema.

Além dos assalariados cujos rendimentos ultrapassam o limite máximo para a contribuição, como conseqüência da centralidade do sistema de seguro social no trabalho assalariado, os funcionários públicos e respectivos pensionistas, os soldados, juízes, religiosos e trabalhadores autônomos não são obrigatoriamente assegurados. Os trabalhadores autônomos não pertencem ao círculo dos segurados do GKV, com exceção de agricultores (proprietários rurais e membros da família que exercem atividades agrícolas na mesma propriedade), artistas e publicitários (Alber, 1992).

Os funcionários públicos (Beamten $)^{50}$ recebem a restituição de $50 \%$ das despesas médicas de sua repartição e costumam contratar um seguro privado para cobrir o restante. Soldados e policiais têm sistema especial de proteção. Para os emprcgados públicos nāo estatutários, por sua vez, as regras são idênticas àquelas dos empregados em geral.

Até 1998, quem exercia a denominada 'ocupação mínima' não cra assegurado. Em 1997, estavam nesta categoria os trabalhadores que recebiam até 610 marcos por mês (510 DM na regiāo oriental) c trabalhavam menos de 15 horas por semana. Estes salários seriam nāo suficientes para garantir a subsistência e as contribuições.

50 O termo funcionário público será utilizado apenas para a traduçāo de Beamten. Nem todos os trabalhadores com empregos estatais são Beamten, uma parte ć composta por empregados públicos. Funcionários públicos, em razão de se pressupor lealdade ao Estado, têm privilégios dilerenciados dos empregados públicos. 
A inclusāo deste contingente de trabalhadores 'precários' ocorreu em 1998 com a coalizão social-democrata/verde. Nos últimos anos, com o crescimento do número de postos de trabalho em tempo parcial, a discussão relativa à inserção deste grupo ${ }^{51}$ no sistema acentuara-se. Verdes e social-democratas defendiam a extensão dos direitos sociais, de modo a incluir mais este contingente populacional. Para os conservadores, o objetivo seria de ampliar a receita do GKV pela inclusão da renda deste tipo de emprego no cálculo das contribuições de quem os exerce como ocupação secundária ou mesmo no caso de cônjuges que se vinculam como dependentes nāo contribuintes, embora exerçam atividades neste nível de remuneração.

$\mathrm{O}$ processo de inclusão de grupos ocupacionais no círculo de segurados compulsórios foi progressivo, ${ }^{52}$ tendo sido incorporado ao GKV, já no início dos anos 70 , a grande maioria da população residente. Todavia, o conjunto de regras de inclusão define os limites da solidariedade inerentes ao próprio sistema.

\section{Segurados voluntários}

A participação voluntária no Seguro Social de Doença (GKV) é possível no início da vida economicamente ativa e como continuidade do asseguramento. Apenas pode filiar-se voluntariamente ao seguro social quem foi seu membro obrigatório nos 12 meses imediatamente anteriores ou quem dele fez parte, durante os últimos cinco anos, por 24 meses no mínimo. Tal situação inclui a possibilidade de participação após a liberação da obrigatoriedade, como, por exemplo, quando o salário ultrapassa o limite obrigatório para o asseguramento. Além disso, a participação voluntária é aberta a assalariados cujos rendimentos ultrapassam esse limite já em sua primeira atividade remunerada.

As regras que dificultam o ingresso de segurados voluntários têm o mesmo sentido daquelas elaboradas para os aposentados: evitar que o indivíduo solteiro ou jovem se beneficie do seguro privado enquanto o prêmio é menor, em virtude

51 Este contingente abrangeria cerca de seis milhōes de trabalhadores, a maioria mulheres. Estas trabalhadoras, apesar de participarem do mercado de trabalho, não usufruem dos mesmos direitos dos outros trabalhadores.

$52 \mathrm{Em} \mathrm{1968,} \mathrm{todos} \mathrm{os} \mathrm{aposentados} \mathrm{foram} \mathrm{incluídos,} \mathrm{desconsiderando-se} \mathrm{o} \mathrm{tempo} \mathrm{prévio} \mathrm{de}$ asseguramento no período ativo, existente desde 1956. Em 1971, o limite máximo do desconto de contribuiçāo do saláuio e de obrigatoriedade de asseguramento foi fixado em $75 \%$ do salário de contribuição ao seguro social de aposentadorias dos operários. Dinamizado por corregão em intervalos regulares, o aumento do limite levou à inclusão de cerca de $60 \%$ dos white-collars como segurados obrigatórios. Pela instituição de Caixas próptias, o seguro-doença dos agricultores autônomos (Landwinte), criado em 1972, incluiu os pequenos proprietários rurais e seus familiares como segurados obrigatórios. Entre 1968 e 1973, cerca de 2,1 milhōes de pessoas até então vinculadas a seguros privados passaram a integrar o seguro social. Em 1975, os deficientes, cerca de 45 mil à época, puderam filiar-se. Em 1975, estudantes e praticantes/ aprendizes foram integrados e, em 1981, na última lei de inclusão de categorias profissionais até o momento, artistas e publicitários autônomos foram obrigados a participar do GKV. 
de apresentar baixo risco e por nāo ter dependentes, recorrendo ao seguro social apenas quando a situação se modifica por casamento ou idade.

\section{Familiares dependentes}

O cônjuge e os filhos do contribuinte são beneficiários do sistema na qualidade de familiares dependentes e estāo isentos de contribuição adicional. Os filhos são dependentes até os 18 anos ou, quando em formação profissional, até 25 anos. $\mathrm{O}$ cônjuge é dependente se não exerce atividade remunerada.

\section{Participação de sequrados e contribuintes por tipo}

Mesmo sendo os familiares diretos isentos de contribuiçāo, a maioria dos filiados ao sistema é contribuinte: $69 \%$. Apenas um em cada três segurados é familiar dependente. Entre os contribuintes, somente $9,7 \%$ o fazem voluntariamente e cerca de $30 \%$ são aposentados..$^{53}$

A proporção de segurados contribuintes, dependentes e aposentados varia muito entre os diversos tipos de provedores de seguros, cujas especificidades serão analisadas no próximo item. Assim, enquanto nas Caixas Substitutas apenas 13\% dos segurados são aposentados, nas Caixas Locais esta proporçāo é de $25 \%$ e na Caixa de Mineiros é de 48\% (BMG, 1996:10.1). Isto produz uma pressão financeira diferenciada entre os órgãos provedores de seguros tanto em razão da utilização, que é maior entre a população mais idosa, quanto pela diminuição das receitas.

Nos últimos dez anos - entre 1985 e 1995 -, a proporção de segurados contribuintes na regiāo ocidental cresceu, enquanto o número de segurados dependentes diminuiu. Isto condiz com o aumento da proporçāo da população economicamente ativa, da mesma forma que é condizente com a baixa taxa de natalidade alemă. ${ }^{54}$ Já a participação dos aposentados no conjunto dos segurados evioluiu mais lentamente do que a proporção de contribuintes - apenas um ponto percentual (BMG, 1996:10.4 e 10.4a).

$\mathrm{Na}$ região oriental, a participação dos contribuintes no conjunto dos segurados é ainda maior. Em 1995, apenas 22\% dos segurados eram dependentes, quer dizer, $78 \%$ eram contribuintes ativos e aposentados, o que pode ser correlacionado à maior proporção da população economicamente ativa no conjunto da população

53 Dados de 1995 para a Alemanha como um todo.

54 Em 1985, 35\% (19,5 milhōes) dos segurados eram dependentes e, em 1995, apenas $31 \%$ (18 milhôes) o eram. A proporção dos contribuintes no conjunto dos segurados, por sua vez, passou de $65 \%$ para $69 \%$. 
em decorrência da tradição socialista de ocupação plena e de estímulo ao trabalho feminino. A proporção de aposentados é também levemente mais elevada do que na rcgiāo ocidental, alcançando 32\% (BMAS, 1996a:10.4a).

Chama a atenção o fato de que, para o Seguro Social de Doença, a evolução da proporção de aposentados não tem os mesmos efeitos que na área da previdência social, na qual aposentado é sinônimo de beneficiário, traduzindo-se o aumento desta relação em equivalente perda do número de contribuintes. No Seguro Social de Doença, a quantidade de contribuintes não diminui quando aumenta a proporção de aposentados entre os segurados, pois estes contribuem do mesmo modo que os ativos. O volume de suas contribuiçôes, contudo, é mais baixo do que o dos contribuintes ativos por causa da perda de renda que envolve a aposentadoria, ao mesmo tempo em que se eleva o risco de adoecer e a probabilidade de utilização.

Durante o período enfocado (1985 a 1996), a proporção de contribuintes voluntários aumentou levemente, tanto entre o conjunto de segurados do GKV (passou de $8 \%$ para 9,1\%) quanto no conjunto de contribuintes (passou de $12,2 \%$ dos contribuintes para $13,2 \%),{ }^{55}$ não confirmando a expectativa conservadora de que os segurados voluntários debandariam para o seguro privado, mais barato para jovens solteiros/as com altos salários e sem dependentes, pois os prêmios são calculados segundo o risco e não como proporção da renda, o que demonstra a alta aceitabilidade contemporânea do GKV.

\section{Catálogo de Ações e Benefícios}

Concomitante ao processo de inclusão de grupos ocupacionais com a extensão de cobertura para camadas cada vez mais abrangentes da população, a pauta de benefícios garantidos pelo GKV - Lcistungskatalog foi ampliada e uniformizada de modo gradual. Na extensão inicial, predominaram as transferências financeiras, principal benefício do GKV em sua origem, tendo sido o auxíliodoença majorado progressivamente em seus valores monetários $\mathrm{e}$ no aumento do período de licença remunerada garantida. ${ }^{56}$

A assistência médica, no início pouco contemplada, tornou-se, aos poucos, o principal setor de gastos do GKV - em particular, a partir de 1930 -, quando os familiares dependentes, cujo asseguramento era garantido apenas em algumas Caixas, foram incluídos na proteção de forma obrigatória. Ações médico-sanitárias

5.5 Dados para a região ocidental. Na regiāo oriental, a proporção de segurados voluntários no conjunto dos segurados é distinta, tendo aumentado de 3,8\%, em 1991, para 5,1\%, em 1996 (BMG, 1997:297).

56 Já $\mathrm{cm} \mathrm{1903,} \mathrm{uma} \mathrm{lei} \mathrm{complementar} \mathrm{duplicou} \mathrm{o} \mathrm{período} \mathrm{de} \mathrm{licença-saúde} \mathrm{para} 26$ semanas. Em 1919, a licença-maternidade foi tornada obrigatória para todas as contribuintes e, posteriormente, alargada muitas vczcs. 
foram sucessivamente incorporadas conforme o desenvolvimento técnico-científico no setor. As despesas com açōes médico-sanitárias individuais, que no começo do século tinham pequena participação no conjunto dos gastos, já representavam, em 1960, 65\% dos dispêndios do GKV (BMG, 1995a).

A introdução de medidas preventivas e de promoção da saúde é mais recente. A prevenção individual, com adoção de medidas para diagnóstico precoce de doenças e direito a consultas médicas periódicas definidas conforme a faixa etária e o sexo, foi incluída no catálogo obrigatório a partir de 1971 e, ulteriormente, várias vezes complementada e estendida a outras doenças. Medidas de promoção foram estabelecidas com maior ênfase apenas em 1989, com a Lei da Reforma da Saúde.

De modo paralelo à ampliação das açōes médico-sanitárias, outros benefícios passaram a ser assegurados, aumentando o campo de atuaçāo do GKV, em particular os relacionados à política de família e saúde reprodutiva e de cuidados de longa duração.

Atualmente, o catálogo de açōes médico-sanitárias e de benefícios em espécie (transferências financeiras) do GKV é uniforme e abrangente. Independente da Caixa a que são afiliados, todos os segurados têm direito a um mesmo catálogo de serviços, definido legalmente no Livro $\mathrm{V}$ do Código Social. A cesta de benefícios engloba quase a totalidade do conjunto de ações diagnósticas e terapêuticas atualmente disponíveis, garantindo atenção médico-sanitária nos diversos níveis de complexidade.

O cerne do catálogo de serviços são as ações médico-sanitárias individuais e, entre estas, as açôes curativas, que incluem: atenção médica ambulatorial e hospitalar; atenção odontológica, assistência farmacêutica, psicoterapia e outros métodos terapêuticos (Heilmittel), bem como cuidados domiciliares (SGB, 1993).

Além das ações individuais curativas, o catálogo inclui: medidas para promoção da saúde, prevenção -inclusive em Kurhaus - e diagnóstico precoce de doenças; ações de reabilitação e meios de ajuda (Hilfsmittel-próteses, lentes de óculos e aparelhos de audição); cuidados na gestação e parto; contracepção para jovens até 20 anos de idade; aborto hospitalar e esterilização legal; fecundação artificial; transferências financeiras: auxílio-doença, auxílio-parto, auxílio-maternidade e auxílio-funeral (SGB, 1993).

As ações não são especificadas em uma cesta, mas definidas de modo genérico. Os segurados têm direito a "tratamento médico quando este se fizer necessário para diagnóstico e cura de doenças, bem como para evitar a piora e minorar o sofrimento" (SGB, 1993:110). As ações devem, pela letra da lei, corresponder a necessidades médicas, ser suficientes, oportunas (estar em consonância com as finalidades) e econômicas (não despender mais recursos do que o necessário). Açôes desnecessárias ou pouco econômicas não podem ser reivindicadas pelos 
segurados, da mesma forma que os prestadores não devem realizá-las, estando as Caixas proibidas de concedê-las (SGB, 1993).

Os segurados têm direito a grande parte das ações do catálogo de forma direta, sem pagamento e sem participação financeira. Para isto, basta apresentar o cartão magnético do segurado. ${ }^{57}$ A participação financeira direta dos pacientes é legislada de modo uniforme entre Caixas e é expressiva apenas para assistência farmacêutica e próteses dentárias. No que concerne à atenção ambulatorial tanto médica quanto odontológica - exceto para próteses e ortodontia - não há participação financeira dos usuários. São estipulados montantes de co-pagamento para medicamentos e para internaçōes em hospitais, clínicas de reabilitação e casas de repouso. Tratando-se de hospitalização, a taxa é paga por, no máximo, 14 dias ao ano. ${ }^{58}$ Uma taxa de participaçāo é definida para os outros métodos terapêuticos (Heilmittel) e para transporte para doentes. Segurados de baixa renda e crianças até 18 anos estão isentos do co-pagamento.

Atualmente, o catálogo não é apenas obrigatório, mas é também único, ou seja, as Caixas não podem criar novos benefícios. Com a uniformização, a possibilidade de oferta de ações adicionais foi sendo reduzida ao longo do tempo. No período da expansão, ações adicionais introduzidas por uma ou outra Caixa foram incorporadas pelo legislador ao catálogo obrigatório, o que o tornou cada vez mais abrangente e homogêneo. ${ }^{59}$

Desse modo, as desigualdades de direitos entre as Caixas são mínimas. Não existem diferenças essenciais no catálogo de ações e benefícios entre as Caixas. Mais de $90 \%$ das açōes do catálogo são definidas legalmente, portanto, as dessemelhanças se referem à maior ou menor facilidade na autorização para alguns serviços, como, por exemplo, para estadia em casas de repouso ou aprovação em orçamentos de próteses dentárias. ${ }^{60}$

Em suma, analisando-se a evolução do catálogo do GKV em seus mais de cem anos de existência, revela-se expansão, progressiva uniformização e mudanças de prioridade na proteçāo. Em sua origem, o núcleo da proteção estava na

57 O cartão magnético, instituído com a Lei de Estrutura da Saúde de 1992, foi implantado plenamente até o final de 1994. Com validade de cinco anos, substituiu as guias de atendimento e, com elas, climinou o emprego de recursos administrativos necessários para impressão, preenchimento etc., porém, permitiu o acesso direto a especialistas, produzindo aumento deste tipo de demanda.

58 Em janeiro de 1997, os valores de co-pagamento por dia de hospitalização eram de 12 marcos (US\$7) na região ocidental e de 9 marcos (US\$5,3) na região oriental. Para $K u r$, eram de 25 marcos e 20 marcos (US\$14,7 e 11,7 ) respectivamente.

59 Com a liberdade de escolha das Caixas, instituída em 1992, a restriçāo legal de oferecimento das açôes adicionais impôs-se como medida de contenção, dado quue a oferta de mais serviços e benefícios, com o fim de atrair maior número de segurados por parte de uma Caixa, poderia ser seguida pelas outras, para não ficarem em pior posição na competição, produzindo aumento de gastos.

60 Em geral, as Caixas Substitutas oferecem maiores facilidades. 
cobertura monetária do risco de adoecer para centrar-se, desde os anos 50, na atenção curativa. Observa-se também a tendência de deslocamento de riscos de curto prazo - medidas curativas - para os de longo prazo - medidas preventivas (Alber,1992). Mais recentemente, o catálogo incorporou medidas preventivas ainda que principalmente individuais. Ações coletivas de promoção e prevenção até hoje são pouco desenvolvidas pelas Caixas. ${ }^{61}$

\section{Catálogo em detalhe}

Além da atençāo médica ambulatorial e hospitalar, os segurados têm direito a uma série de outras açōes médico-sanitárias, descritas a seguir.

\section{Promoção, prevenção e diagnóstico precoce}

Entre as medidas de promoção e prevenção à saúde estão incluídas medidas individuais, inclusive em regime de internação, e coletivas: informação e educação em saúde para a prevenção de doenças; profilaxia individual e de grupo para saúde bucal; medidas de promoção em regime de internação em casas de repouso (Kurhaus); estadia preventiva em casas de repouso para mães (Müttergenesungskuren).

A prática preventiva é principalmente individual, com ênfase no diagnóstico precoce e de acompanhamento do desenvolvimento infantil; conquanto tenha sido aberta recentemente às Caixas a possibilidade da definição de parcerias com outros atores dos programas de saúde coletiva e permitida a sua participação no financiamento.

As ações de promoção da saúde são efetuadas principalmente mediante 'programas' ou 'treinamentos' de saúde relativos a: temas clássicos de prevenção individual, mudanças de hábitos e combate ao estresse. Afora isso, as Caixas fazem atividades de promoçāo à saúde e prevenção de acidentes nas empresas, em parceria com elas. ${ }^{62}$

Igualmente considerada medida preventiva é a atenção prestada nas casas de repouso, nos casos em que se verifique estar o "estado de saúde do segurado debilitado, o que em prazo previsível levará ao adoecimento” (BMAS, 1994). Nessas situaçōes constatadas pelo médico, o segurado tem direito a cuidados em

61 Ações de vigilância em saúde e controle coletivo competem a departamentos governamentais específicos de saúde.

62 Esta é uma atividade secundária, pois a prevenção, tratamento e reabilitaçāo de acidentes de trabalho sāo de competência específica do seguro de acidentes de trabalho. 
casa de repouso tipo SPA, ${ }^{63}$ em regime de internação ou ambulatorial. Todos os segurados com indicação médica têm direito a três semanas de SPA a cada quatro anos. ${ }^{64}$ Medida semelhante é prevista também para a diminuição do estresse de mães com filhos pequenos.

Desde 1993, além dessas medidas de promoção e prevenção, as Caixas têm a possibilidade de repassar recursos para incentivar grupos de auto-ajuda e entidades não lucrativas de promoção e reabilitação da saúde.

\section{Assistência odontológica}

A atenção odontológica inclui medidas preventivas de saúde bucal, de diagnóstico precoce, curativas e de reabilitação - inclusive ortodontia para menores de 18 anos. Os segurados têm livre escolha. Podem optar pelo profissional de sua preferência entre os dentistas credenciados, que são a grande maioria, sendo atendidos em seus consultórios privados.

A maioria das ações odontológicas está incluída no catálogo ${ }^{6.5}$ e a atenção é, em geral, gratuita, podendo ser utilizada sem necessidade de desembolso por parte do segurado. Faz-se exceção para próteses e ortodontia, nas quais os pacientes têm expressiva participação nas despesas, que são restituídas em $80 \%$ para tratamento ortodôntico e em $50 \%$ dos gastos para próteses dentárias. Para tal, o orçamento do tratamento deve ser previamente aprovado pela Caixa. Como estímulo ao maior cuidado individual com os dentes, os segurados que visitam o dentista regularmente - uma vez ao ano - têm direito à restituição de $60 \%$ dos gastos com próteses. ${ }^{60}$

De modo predominante, a profilaxia na assistência odontológica tem sido realizada por meio de consultas de rotina individuais. Apenas em época recente, as medidas de profilaxia de grupo receberam maior ênfase e foram introduzidas

63 A estadia em Kurhaus para recuperação da saúde ou prevenção do surgimento de agravos é prática tradicional na Alemanha. Banhos; massagens e exercícios compöem o programa. Inúmeros balneários e estações termais especializaram-se nesta forma de atenção (e ramo da economia). Após o tratamento de doença grave, câncer de mama, por exemplo, tal estadia constitui a oportunidade de atenção integral, em que se une o atendimento médico clássico à psicoterapia individual e/ou de grupo, com técnicas alternativas de combate ao estresse, medidas educativas para mudança de hábito alimentares, além dos banhos e ginásticas habituais.

64 Até 1996 eram quatro semanas a cada três anos, períodos estes reduzidos com o pacote econômico (Sparpaket) de 1996.

6.5 Estão excluídos alguns materiais de restauração e cerâmica para próteses, assim como certos procedimentos, como os implantes de dentes. Para prótese deline-se um número máximo de dentes por semi-arcada e de pontes por arcada.

66 Nos últimos anos, a participação dos pacientes nas despesas com próteses dentárias sofreu alterações tanto na forma quanto no montante. Pela lei de contenção de gastos de 1997, a participação percentual das Caixas nessas despesas foi substituída pelo subsídio fixo por tipo de próteses. 
como obrigatórias. ${ }^{67}$ Medidas de profilaxia de grupo devem ser realizadas pelas Caixas em jardins de infância e escolas para crianças até 12 anos em parceria com os departamentos locais de saúde e a Associação de Dentistas das Caixas.

A baixa ênfase nos aspectos preventivos reflete-se no estado de saúde bucal. Assim, embora os gastos com assistência odontológica sejam dos mais altos em comparação com os demais países, a saúde bucal infantil na Alemanha é pior do que em países com gastos menorcs ou de igual nível (Alber, 1992). O recente destaque dado à introdução de ações profiláticas individuais e coletivas - altamente positivas no sentido de evitar as cáries e garantir a preservação dos dentes busca dar resposta a esta situação problemática, mas tem também um componente de contençāo. Caso os segurados se submetam à profilaxia, espera-se que não venham a necessitar de próteses. No entanto, a despeito de as medidas profiláticas compartilharem objetivos restritivos, sua introdução não tem efeito imediato de contenção de custos. Como as medidas preventivas são de caráter individual, sua implementação produz aumento de gastos, em razão de haver mais um exame periódico por segurado.

\section{Assistência farmacêutica}

Os medicamentos necessários à atenção ambulatorial também estāo incluídos na cesta. A distribuição é feita diretamente pela rede de farmácias privadas e é afiançada por meio de contratos estabelccidos entre as Caixas e as Associações das Farmácias. Para receber um medicamento, o segurado apresenta a receita em qualquer farmácia e paga o montante de co-pagamento. Os medicamentos são pagos pelas Caixas diretamente às farmácias.

A assistência farmacêutica é o único setor da atenção em que há expressiva participação financeira direta dos pacientes mediante taxas de co-pagamento. Ao aviar uma receita na farmácia, o paciente paga uma taxa fixa, escalonada conforme o número de doses contido na embalagem: grandes, médias e pequenas.

Os valores do co-pagamento, assim como o volume de medicamentos englobados no esquema, foram sucessivamente ampliados nos últimos anos. Ao mesmo tempo, a implementação das regras de participação dos usuários nos gastos tornou-se cada vez mais complicada, como será visto na análise das medidas de contenção.

Tradicionalmente, existe pouco controle dos preços de medicamentos na Alemanha, e os remédios são considerados caros em comparação com outros países europeus (Alber, 1992). Até 1989, a interferência das Caixas na formação dos preços de medicamentos era mínima. Naquele ano foi criado um sistema de

67 Em 1989, tornaram-se obrigatórias medidas de profilaxia de grupo para escolares, reforçadas em 1997. 
definição de preços máximos para grande parte dos medicamentos a serem pagos pelas Caixas às farmácias. Se o preço do medicamento for mais elevado do que o valor máximo fixado, o médico deve informar ao paciente que o está receitando e o segurado deve arcar com a diferença.

O preço da maioria dos medicamentos incluídos no sistema, porém, foi ajustado ao valor fixado logo após a primeira definição de preços máximos e a maior parte não ultrapassa hoje o preço máximo. Com esta forma de regulação de preços, as possibilidades de intervenção das Caixas foram ampliadas, em especial,

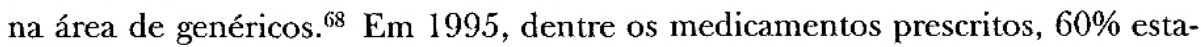
vam englobados neste sistema, correspondendo a $56 \%$ das despesas do GKV com assistência farmacêutica (AOK, 1996).

A influência das Caixas restringe-se aos preços, sendo difícil influir na qualidade das prescrições. $\mathrm{O}$ controle da qualidade dos medicamentos disponibilizados no mercado é também considerado pouco desenvolvido. Inúmeros daqueles proscritos em países como Inglaterra ou EUA por seus efeitos duvidosos são licenciados na Alemanha (Schwabe \& Paffrath, 1996). A prescrição de genéricos vem crescendo de modo gradual; representava, em 1995, 38,6\% das prescrições, o que corresponde a $29,8 \%$ dos gastos das Caixas com medicamentos. Estima-se um potencial de economia de 2 bilhōes de marcos anuais caso fossem realizadas todas as prescrições possíveis com genéricos (Schwabe \& Paffrath, 1996). Entretanto, nenhuma nova medida para estimular o uso de genéricos tem sido promovida.

\section{Meios de cura e meios de ajuda}

Os segurados têm direito à grande maioria das ações sanitárias prestadas por outros profissionais da área da saúde quando prescritas pelos médicos, os chamados 'outros métodos terapêuticos' ou 'outros meios de cura' (Heilmittel). O tratamento com estes métodos é diferenciado daquele com emprego de medicamentos, sendo descrito como tratanentos com base em ações externas sobre o corpo das pessoas e prestado por profissionais não médicos. Inclui principalmente açōes terapêuticas físicas, tais como ginásticas especiais para doentes, massagens, banhos medicinais, fisioterapia, assim como fonoterapia e terapias ocupacionais.

Estas açōes somente podem ser efetuadas por prestadores credenciados. As Caixas, em conjunto, decidem quais as profissōes passíveis de serem credenciadas. Com a lei da Reforma da Saúde, introduziu-se, desde 1989, a participação dos pacientes com mais de 18 anos nas despesas com estas ações. Até 1997, a taxa de co-pagamento para Heilmittel era de $10 \%$ dos gastos. A partir de julho de 1997 passou a $15 \%$.

68 No caso de novos medicamentos, esta possibilidade inexiste, pois os mesmos são excluídos da negociação de preços. 
Outro dos componentes do catálogo, os 'meios de ajuda' (Hilfsmittel) visam a assegurar o sucesso do tratamento médico ou compensar uma deficiência. Os principais são lentes de óculos e aparelhos de audição, próteses corporais e aparelhos ortopédicos. Havendo deficiência física, são garantidos equipamentos sofisticados, como próteses com mecanismos microeletrônicos e cadeiras de rodas motorizadas.

Assim como para os medicamentos, com a Lei da Reforma da Saúde, em 1989, foi introduzido um sistema de preços máximos para os 'meios de ajuda' a serem pagos pelas Caixas. $\mathrm{O}$ sistema teria por objetivo evitar a participação financeira dos pacientes e estimular os produtores a oferecer produtos no preço fixado (BMAS, 1994).

\section{Cuidados domiciliares}

O segurado, além de tratamento médico, tem direito a cuidados domiciliares. Quando estes podem reduzir o tempo de internação hospitalar, o segurado recebe em seu domicílio cuidados básicos, terapêuticos e ajuda para serviços domésticos durante até quatro semanas por agravo.

\section{Reabilitação}

Ações de reabilitação para prevenir, eliminar ou melhorar deficiências e 'dependência de cuidados' integram o catálogo obrigatório. A atenção reabilitadora pode ser prestada pelo médico em seu consultório, oferecida na forma de um Kur ambulatorial para reabilitação, ou sendo a forma ambulatorial insuficiente èm regime de internação hospitalar. Esta é feita em clínicas de reabilitaçāo contratadas pelas Caixas. Em geral, a possibilidade de reabilitação hospitalar restringe-se a quatro semanas no intervalo de três anos. As regras de co-pagamento da internação para reabilitação são idênticas às das internações em geral.

Se a reabilitação é direcionada para restabelecimento da capacidade de trabalho do segurado, esta passa a ser competência da Previdência Social (Rentenversicherung). Quando a necessidade de reabilitação é decorrente de acidente de trabalho, torna-se responsabilidade do seguro social de acidentes.

\section{Transferências financeiras}

Além de açōes médico-sanitárias, os segurados têm direito também a benefícios em espécie: auxílio-doença, licença-maternidade, auxílio-parto, auxílio-funeral (para segurados que se filiaram ao sistema até 1989$)^{69} \mathrm{e}$ auxílio doméstico em caso de doença.

69 O auxílio-funeral por morte do contribuinte é de 2.100 marcos e, no caso da morte de familiar, de 1.050 marcos (1997). 
O auxílio-doença é pago pelo GKV a partir da sétima semana de licença para tratamento de saúde por, no máximo, 78 semanas para a mesma doença ${ }^{70}$ a cada período de três anos. Seu valor, até 1996, era de $80 \%$ do salário de contribuição. Nas seis primeiras semanas, a continuidade do pagamento do salário é encargo do empregador e, desde 1969, é igual para operários e empregados, correspondendo a $100 \%$ do salário habitual sem carência.

Em 1996, reduziu-se o auxílio-doença para 70\% do salário de contribuição e o pagamento nas seis primeiras semanas de afastamento foi legalmente estipulado como, no mínimo, $80 \%$ do salário habitual. Contudo, esta redução dos salários pagos no caso de docnça nāo se concretizou por pressão dos trabalhadores nas negociações dos acordos coletivos setoriais, embora concessões tivessem de ser feitas.

As mulheres empregadas, além da necessária atenção médica durante a gravidez $\mathrm{e} o$ parto, têm direito à licença-maternidade por seis semanas antes do parto e oito semanas depois. Uma parcela do salário correspondente ao período da licença-maternidade é pago pelas Caixas e outra pelos empregadores ${ }^{71}$ Seguradas não empregadas recebem pequeno auxílio-parto.

Além do direito da trabalhadora ou do trabalhador à remuneração no caso de afastamento do trabalho para tratar de filho doente, o GKV garante outro benefício monetário: ajuda financeira para realização das tarefas domésticas (Haushaltshilfe) no caso de internação da mãe ou pai de filhos de até 14 anos, na ausência de outro adulto no lar que possa cumprir estas tarefas.

\section{Composição e Organização}

A organização do Seguro Social de Doença alemão caracteriza-se pela articulação e pluralidade das instituições responsáveis por asseguramento. Isto é, a proteção não é organizada com base em diferentes provedores de seguros articulados em associações específicas. A pluralidade de Caixas tem origem na forma histórica de constituição do GKV e sua continuidade foi garantida pela adscrição compulsória de grupos populacionais diferenciados conforme a inserçāo ocupacional em tipos diversos de Caixas.

A existência de regras específicas para o asseguramento de grupos ocupacionais distintos e/ou com status diferenciados - como, por exemplo, operá-

70 Após este período pode-se ter acesso a benefícios do sistema de aposentadorias.

71 Atualmente, os empregadores pagam cerca de $3 / 4$ do auxílio maternidade, segundo a Associação Alemã de Empregadores - DBA (DBA, 1994:21). Afora isso, a mãe ou o pai tem direito à licença sem vencimentos com garantia do emprego e ajuda finaceira durante 18 meses por ocasiăo do nascimento de filho (Erziehungsurlaub ou Erzichungsgeld). Em 1996, esta ajuda era de 600 marcos mensais no máximo (escalonada segundo a renda familiar) e extensivo a mães e pais trabalhadores. 
rios (blue collar) e empregados (white collar), mineiros e marítimos - levou à constituição e/ou manutenção de Caixas de Doença (Krankenkassen) separadas, organizadas por ramo de produção, empresa, profissão ou região.

Desse modo, nos dias atuais, o Seguro Social de Doença é composto por distintos tipos de Caixas de Doença (Krankenkassen) com vinculação por ramo de produção, empresa, profissão ou região. As Caixas são classificadas em oito tipos. Em 1997, existiam, na Alemanha como um todo, 554 Caixas; entre estas, 18 eram 'Locais' (AOK - Ortskrankenkassen), 457 de 'Empresas' (BKK Betriebskrankenkassen), 43 de 'Corporações de Trabalhadores Manuais' (IKK Innungskrankenkassen), 20 'Rurais' (Landwirtschaftliche Krankenkassen), 7 'Substitutas para Empregados', 7 'Substitutas para Operários' (Ersatzkassen), uma de 'Marítimos' (Seekrankenkasse) e uma de 'Mineiros' (Bundesknappschaft). Esta tipologia define a forma de organização das representações das Caixas, que se agrupam em associações correspondentes.

Até 1995, a adscrição a tipos específicos de provedores de seguro social era compulsória. A lei definia em qual tipo de caixa um indivíduo deveria assegurar-se. Os operários eram obrigados a afiliar-se à Caixa Local de sua região. Às Caixas de Empresas e de Corporações pertenciam os respectivos trabalhadores. Os 'empregados' desfrutavam o privilégio de optar entre uma Caixa Substituta e uma Local.

A Lei da Estrutura da Saúde de 1992 ampliou o direito de eleição da Caixa pelos segurados, e a grande maioria dos contribuintes passou a poder escolher aquela de sua preferência. Como veremos no capítulo V, desde 1997, cerca de 85\% dos contribuintes podem optar pela Caixa que quiserem, sem restrições.

Ainda que a pluralidade de órgãos provedores de seguro permaneça como característica do GKV, ao longo do tempo houve importante processo de concentraçăo. Paralelamente à inclusão de parcelas cada vez mais ampliadas da população ao GKV, a quantidade de Caixas diminuiu de modo drástico no transcorrer dos anos, elevando-se o número de segurados por órgão. As cerca de 21 mil Caixas existentes no início do século (1913/14) sofreram brusca redução nos anos de 1920, passando para 7,7 mil em 1924/25. Em 1949/50, quando da constituição da República Federal Alemã, existiam cerca de 2 mil e, desde então, este número continuou a diminuir de modo gradual (Alber, 1992). Nos últimos 25 anos, o número de Caixas foi reduzido para cerca de um terço.

Recentemente, o processo de concentração de órgãos provedores de seguro acelerou-se. A possibilidade de fusão entre Caixas foi facilitada pela Lei da Estrutura da Saúde (GSG) de 1992. Caixas Locais, de Empresas e de Corporaçōes, a partir de 1994, empreenderam esse processo com o intuito de diminuir custos operacionais e colocarem-se em melhores condições para enfrentar a competição pela conquista de segurados. A tabela abaixo mostra a distribuição das Caixas por tipo desde 1970, podendo-se observar o processo de concentração descrito. 
Tabela 4 - Caixas por tipo e região. Alemanha - anos selecionados

\begin{tabular}{|c|c|c|c|c|c|c|}
\hline Ano & Local & Empresa & Corporação & Rural & Substitutas & TOTAL* \\
\hline \multicolumn{5}{|c|}{ Regiāo da Alemanha Ocidental } & . & \\
\hline 1970 & 399 & 1.119 & 178 & 102 & 15 & 1.815 \\
\hline 1975 & 314 & 965 & 164 & 19 & 15 & 1.479 \\
\hline 1980 & 272 & 655 & 156 & 19 & 15 & 1.319 \\
\hline 1985 & 270 & 754 & 155 & 19 & 15 & 1.215 \\
\hline 1990 & 267 & 692 & 152 & 19 & 15 & 1.147 \\
\hline 1994 & 223 & 653 & 139 & 19 & 15 & 1.051 \\
\hline 1995 & 84 & 633 & 122 & 19 & 15 & 875 \\
\hline 1996 & 12 & 485 & 39 & 18 & 15 & 571 \\
\hline 1997 & 12 & 424 & 28 & 18 & 14 & 498 \\
\hline \multicolumn{7}{|c|}{ Região da Alemanha Oriental** } \\
\hline 1991 & 12 & 37 & 23 & 2 & 0 & 74 \\
\hline 1994 & 12 & 66 & 21 & 2 & 0 & 101 \\
\hline 1995 & 8 & 57 & 18 & 2 & 0 & 85 \\
\hline 1996 & 8 & 47 & 14 & 2 & 0 & 71 \\
\hline 1997 & 6 & 33 & 15 & 2 & 0 & 56 \\
\hline
\end{tabular}

* O número de Caixas refere-se ao início do ano, exceto para 1970, que corresponde ao final do ano. O total, para a região ocidental, inclui a Caixa dos Marítimos c a Caixa dos Mineiros em todos os anos. ** Caixas com sede na região oriental.

Fonte: BMG, 1995a:280; BMG, 1997:294; BMG, 1996.

As principais Caixas de Doença são as Locais, com 23 milhōes de segurados, e as Substitutas para Empregados, com 21 milhões, garantindo proteçāo à maioria da população. Às Caixas Locais estão associados cerca de $40 \%$ dos segurados do GKV e às Substitutas para Empregados, por volta de 35\%. Já as de Empresas e de Corporaçōes, por tradição mais numerosas e menores, são responsáveis por $12 \%$ e $6 \%$ dos segurados do GKV, respectivamente.

Refletindo mudanças na própria estrutura produtiva - diminuição da proporção de trabalhadores industriais e expansão do setor de serviços -, a cobertura das Caixas Locais e Substitutas modificou-se ao longo do tempo. As Substitutas para Empregados tiveram sua clientela ampliada, assegurando de modo progressivo maior parcela da população, e as Locais perderam importância relativa, pois seu número de segurados cresceu mais lentamente. Assim, como se pode observar na tabela abaixo, enquanto $52 \%$ dos contribuintes ${ }^{72}$

72 O termo 'contribuintes' inclui aposentados e exclui dependentes. Em razāo das diferenças entre as Caixas quanto ao número de dependentes assegurados, as proporçōes de segurados e contribuintes são levemente distintas. 
estavam filiados, em 1970, às Caixas Locais e apenas $23 \%$ às Substitutas, estas proporções eram respectivamente de $41 \%$ e $36 \%$ em 1995.

Tabela 5 - Proporção de contribuintes por tipo de Caixa. Alemanha Ocidental - 1970-1995

\begin{tabular}{cccccccccc}
\hline Ano & Local & Empresa & Corp. & Rural & Marítimo & Mineiro & S. Oper. & \multicolumn{2}{c}{ S. Empr. Total } \\
\hline 1970 & 52,4 & 13,6 & 4,6 & 1,4 & 0,3 & 3,7 & 1,1 & 22,9 & 100 \\
1975 & 48,3 & 12,7 & 4,7 & 2,8 & 0,2 & 3,2 & 1,1 & 27,0 & 100 \\
1980 & 46,7 & 12,1 & 5,1 & 2,5 & 0,2 & 2,9 & 1,2 & 29,3 & 100 \\
1985 & 44,8 & 11,6 & 5,2 & 2,2 & 0,2 & 2,7 & 1,5 & 31,8 & 100 \\
1990 & 43,2 & 11,8 & 5,2 & 1,9 & 0,1 & 2,5 & 1,7 & 33,6 & 100 \\
1995 & 41,2 & 11,2 & 5,5 & 1,6 & 0,1 & 2,2 & 2,1 & 36,0 & 100 \\
\hline
\end{tabular}

Fonte: BMG, 1997:299. Para 1960: Alber, 1992:67.

As Caixas Substitutas para Empregados são as maiores, tendo em média mais de dois milhōes de beneficiários. As Caixas Locais, tradicionalmente menores devido à sua forma de organização regional, contam também, desde 1996, com mais de 2 milhões de segurados, em média, como conseqüência do processo de fusão que empreenderam em nível estadual. ${ }^{73}$

\section{Caixas Locais}

Às Caixas Locais (Allgemeine Ortskrankenkassen/AOK) tradicionalmente pertenciam todos os segurados obrigatórios para os quais não existem Caixas específicas - os operários, blue collars - e eram organizadas por região geográfica sob a regulação dos governos estaduais. Até a década de 1980 eram constituídas em âmbito municipal ou por grupos de municípios próximos. Em sua origem, as Caixas Locais eram especializadas, constituídas por profissão ou ramo de produção. No início do século, após processo de fusão, foram dirigidas aos operários em geral. Estas Caixas Locais unificadas tiveram, desde seus primórdios, o apoio dos sindicatos e da social-democracia e, em geral, estão ligadas à Central Sindical DGB (Deutscher Gewerschaftsbund).

Em 1996, 40\% de todos os beneficiários do sistema (47\% dos segurados obrigatórios) eram membros de Caixas Locais (BMG,1997). As Caixas Locais contam com baixo número de contribuintes voluntários; apenas $25 \%$ de todos os contribuintes voluntários. Cerca de $60 \%$ dos membros voluntários do sistema contribuem para Caixas Substitutas (StBA, 1995a).

73 Até 1990 tinham em média 87 mil segurados (BMG, 1995:280, 285; StBA, 1995a:47, cálculos próprios). 
As Caixas Locais apresentavam taxas de contribuição muito diferenciadas, bem como importantes dificuldades financeiras em alguns locais como decorrência de sua forma de organização regional; no entanto, a partir de 1994 passaram por processo de concentração como estratégia de fortalecimento frente à anunciada competição ampliação da liberdade de escolha das Caixas pelos segurados. Unificaram-se regionalmente, estando o seu número reduzido a quase um terço em 1995. No ano seguinte, as Caixas Locais implementaram uma estratégia de unificação em nível estadual. Desde 1996, existe apenas uma Caixa Local por Estado, com exceção dos Estados Nordrhein-Westfalen e Sachsen-Anhalt, cada qual com duas (BKK 1997). ${ }^{74}$

Este processo de concentração tende a avançar, em especial, pelas dificuldades financeiras de Caixas Locais da regiāo oriental, à beira da ruína ante as imposiçôes da nova legislação que as pressiona a aumentar as taxas de contribuição. A tendência atual seria a de criação de Caixas por grandes regiões, uma vez que o processo de estadualização já se completou. A fusão de Caixas ampliaria as transferências financeiras - redistribuição - entrc regiões com distinto desenvolvimento econômico, o que é consoante com o princípio da solidariedade (Am Orde, 1997b)..$^{75}$

Se, por um lado, o processo de concentração facilitou a tarefa de representação de interesses das Associaçōes de Caixas frente aos prestadores e produziu possível redução de custos de administração, por outro, a quantidade de membros por caixa é de tal ordem que dificulta cada vez mais a identificação ativa dos segurados com suas Caixas (Alber, 1992).

Com a expansāo das Caixas, a administração autônoma perdeu em proximidade com os segurados e em suas funçōes de acompanhamento e aconselhamento, tornando-se estruturas cada vez mais burocráticas. No presente, estes órgãos são grandes organizaçōes burocráticas, cujos dirigentes/representantes quase não podem mais ter relação direta com as bases. Os cargos de gestão, antes ocupados por sindicalistas engajados, são preenchidos por gerentes profissionais que tanto poderiam ocupar este como outro cargo em qualquer associação de prestadores.

\section{Caixas de Empresas}

As Caixas de Empresas (Betriebskrankenkassen/BKK) asseguram os seus trabalhadores. Podem ser criadas pelos empresários para uma ou mais de suas empresas. Para a criação do órgão, as empresas devem ocupar, no mínimo, 1.000 .

74 O processo recente de fusão teve a oposição de muitos dos representantes nos Conselhos de Administração. Com a diminuição do número de Caixas, a quantidade de postos de representantes foi reduzido à metade a cada duas Caixas fundidas.

75 Uma fusão de Caixas de diferentes regiōes sofreria maior resistência. As Caixas na região oriental estão cm pior situação linanceira (Betina Am Orde, 1997a). 
trabalhadores com obrigatoriedade de asseguramento, contar com a aprovação da maioria dos trabalhadores e a autorização da repartição governamental competente. Criada uma Caixa, todos os segurados obrigatórios ocupados na empresa passam automaticamente a ser seus membros.

Por agregarem apenas os trabalhadores de cada empresa, o número médio de segurados por Caixa de Empresa é o menor - cerca de 13 mil. Embora a maioria das Caixas esteja organizada por empresa (81\%), asseguram apenas $11 \%$ do conjunto de beneficiários do GKV.

\section{Caixas de Corporações}

É permitido às corporaçōes de profissionais criar Caixas para seus associados. Das Caixas de Corporaçōes (Innungskrankenkassen/IKK) participam os trabalhadores ocupados em empresas de 'ofícios manuais' (Handwerksbetrieb), como eletricistas, serralheiros, alfaiates, marceneiros, relojoeiros e padeiros, cujos proprietários sejam membros da corporação. As regras de criação são similares àquelas para empresas (SGB, 1993). Em 1995 existiam 122 Caixas de Corporações, com a média de 27 mil segurados, na região ocidental. No entanto, essas Caixas também aderiram à estratégia de fusão e, em 1997, seu número foi reduzido a 28 , passando cada qual a contar, em média, com 114 mil segurados.

\section{Caixas Rurais}

As Caixas Rurais (Landswirtschaftliche Krankenkassen/LKK) sāo organizadas pelas cooperativas rurais e delas fazem parte os pequenos e médios proprietários rurais que trabalham em regime de economia familiar. Este foi um dos últimos segmentos populacionais incluídos no GKV. As primeiras Caixas Rurais foram criadas no início dos anos 70 com subsídios da União, que permanecem até hoje. Por não terem sido incluídas na competiçāo, o número de Caixas Rurais temse mantido constante; estas, em geral, sempre foram maiores e sua clientela permanece compulsória e fechada. Em 1995, na região ocidental, existiam 19 Caixas Rurais, com cerca de 67 mil beneficiários por instituto.

\section{Caixas dos Marítimos e dos Mineiros}

Paralelamente aos órgãos provedores de seguro organizados em nívcl regional ou local, existe ainda uma Caixa para os trabalhadores de minas e outra para marítimos, organizadas em nível nacional. Em 1996, a Caixa dos Marítimos (Seekrankenkasse) contava com 64 mil beneficiários e a Caixa dos Mineiros 
(Bundesknappschaft) com 1,2 milhôes de beneficiários. Estas Caixas, assim como as Rurais, mantêm sua clientela restrita e têm particularidades em seu financiamento. Recebem subsídios especiais por protegerem grupos populacionais com características específicas, como é o caso dos mineiros, que têm maior risco de doenças profissionais e cujo setor passa por importante reestruturação, em razão tanto da substituição do carvão por outras formas de energia quanto dos baixos preços internacionais do produto, que tornam o carvão alemão não competitivo mesmo internamente.

\section{Caixas Substitutas}

As Caixas Substitutas têm sua origem vinculada a fundos de auxílio independentes (Freie Hilfskassen), existentes à época da lei do Seguro Social de Doença, ao final do século XIX; às quais permaneceram filiados os trabalhadores não obrigados de asseguramento. Reconhecidas em 1909 como Caixas Substitutas, determinada clientela de empregados foi-lhes adscrita legalmente. Por tal origem, as Caixas Substitutas guardam até hoje características especiais, como é o caso da sua administração apenas pelos segurados à diferença da maioria das entidades provedoras de seguro social, que são geridas de forma paritária.

Estas Caixas, no início, eram mais apreciadas tanto pelos patrões - por não estarem obrigados a contribuir - quanto pelos trabalhadores - por serem autogeridas. Desde o início do século, porém, os trabalhadores organizados social-democracia e sindicatos - afastaram-se destas entidades, atuando mais nas Caixas Locais (Oliveira, 1995).

As 'Caixas Substitutas para Operários' (Ersatzkassen der Arbeiter/EAR) são organizadas regionalmente ou por ramo de produção e, até 1996/97, só podiam filiar operários de determinadas categorias. São apenas oito e têm pouca expressāo pelo baixo número de segurados que congregam (apenas $2 \%$ dos contribuintes).

As 'Caixas Substitutas para Empregados' (Ersatzkassen der Angestellten / EAN), ao contrário, são organizadas nacionalmente, com taxa de contribuiçāo única para todo o país e são em número de sete. ${ }^{76} \mathrm{~A}$ afiliação às Caixas Substitutas não é compulsória. Os trabalhadores classificados como empregados desfrutam da liberdade de escolha, podendo inscrever-se em Caixa Local ou em Caixa Substituta. Todavia, até 1996, as Caixas Substitutas podiam definir o círculo de afiliados em seus estatutos. Atualmente, estão abertas a todos os segurados e são obrigadas a aceitar qualquer contribuinte. ${ }^{77}$

Barmer, Deutsche, Hamburg-Münchener, Handels-, Hanseatische, Kaufmannische, Techniker. Agradeço a Walter Baumann, gerente da representação regional em Hessen de uma Caixa Substituta (Techniker Krankenkasse) pelas informaçôes a respeito das particularidades destas Caixas e quanto ao processo de negociação de preços com as Associaçōes de Médicos, em entrevista realizada em Frankfurt em junho de 1997. 
As Caixas Substitutas, em geral, por conta de suas receitas mais elevadas, em comparação às Caixas Locais, ofereciam benefícios ampliados, garantindo privilégios aos seus segurados (Baumann,1997). Hoje, porém, evidencia-se uma diferenciação entre as diversas Caixas Substitutas. As maiores comumente têm estrutura de riscos semelhantes às das Caixas Locais e apenas algumas Caixas Substitutas menores, com clientelas restritas a setores profissionais mais qualificados, garantem alguns privilégios aos seus segurados.

Outra diferença entre as Caixas Locais e Substitutas é a vinculação com os sindicatos, que decorre da adscrição, até 1996, de clientelas específicas. A Central Sindical (DGB-Deutscher Gewerkschaftsbund) tem pouca influência nas Caixas Substitutas, pois estas são reduto tradicional do (DAG-Deutsche Angestelltengewerkschaft), Sindicato dos Empregados Alemães, menos atuante e combativo, que não é filiado à DGB. Este é um dos fatores que contribuíram para a rivalidade entre as Caixas. ${ }^{78}$

As diferenças entre as Caixas se expressam também em conflitos entre elas, traduzindo divergência parcial de interesses e concorrência. Os conflitos mais marcantes ocorrem entre as Caixas Locais e as Substitutas. As primeiras, tipicamente de operários, defenderiam interesses mais gerais da massa trabalhadora, $\mathrm{e}$ as Caixas Substitutas, privilégios de alguns grupos ocupacionais. As Caixas Locais - tradicionalmente direcionadas a operários - têm estrutura de riscos menos vantajosa e, por isso, condições financeiras menos favoráveis. As Caixas Substitutas, em especial algumas de grupos específicos de empregados em melhor situação financeira, podem oferecer facilidades adicionais e, em geral, negociam contratos de remuneração generosos com os médicos, pagando preços mais altos e buscando, em contrapartida, atendimento diferenciado para seus segurados. Estas conquistaram, assim, parcela maior de segurados voluntários. ${ }^{79}$

A diversidade de Caixas originalmente correspondia à heterogeneidade de benefícios entre grupos ocupacionais. Ao longo do tempo, como vimos, o catálogo de ações e benefícios foi tornando-se homogêneo, reduzindo-se privilégios. Nos dias atuais persistem poucas diferenças entre as Caixas. Permanecem, contudo, diferenças nas taxas de contribuição devido à adscrição compulsória de grupos populacionais com riscos diferenciados a tipos de Caixas específicos.

Embora o número de Caixas venha diminuindo de modo intenso nos últimos anos, em decorrência da intensificação do processo de concentração deslanchado pela introdução dos mecanismos de competição, a pluralidade de provedores de seguro social ainda é característica do GKV.

78 Em razão das dificuldades de renovação dos ocupantes destes cargos, torna-se difícil para a DGB aumentar aí sua influência, o que poderia levar as Caixas a uma atuação política mais coadunada (Am Orde, 1997a).

79 Competição por segurados voluntários, tradicionalmente detentores de livre escolha sempre existiu. 
A articulação entre as diversas Caixas por tipo, outra característica básica do sistema, é garantida mediante sua organizaçāo em associaçōes, nos níveis estadual e nacional, como órgãos de direito público. As Caixas Locais, depois de sua fusão e unificação em cada estado em 1996, organizam-se, desde então, apenas em nível nacional. As Caixas Substitutas, por sua vez, sempre se organizaram somente em nível nacional, e suas associações - das Caixas Substitutas para Empregadores e das Caixas Substitutas para Operários - são de direito privado. São estas associaçōes estaduais/nacionais que negociam com os prestadores (associaçōes de médicos credenciados, sociedades de hospitais e outros) os contratos de atenção e as formas de remuneração e preços, dentro dos limites estipulados pela legislação. Representam também as Caixas na Ação Concertada em Saúde e compõem comissōes conjuntas com prestadores, constituindo-se dos mais importantes atores setoriais.

\section{Financiamento}

O financiamento do Seguro Social de Doença é garantido através de contribuições compulsórias de empregados e empregadores. ${ }^{80}$ De acordo com o princípio da solidariedade, as contribuições mensais dependem da capacidade financeira dos segurados, correspondendo a certa proporção dos salários. $\mathrm{O}$ valor das contribuições não é, portanto, escalonado segundo o risco; independe do estado de saúde, idade, sexo ou número de dependentes do segurado.

O Seguro Social de Doença (GKV) é financiado quase exclusivamente pelas contribuições $(96 \%)$. Ao contrário dos países onde a proteção é garantida via Sistema Nacional de Saúde com financiamento fiscal, a participaçāo estatal no seguro social é exceção. A União contribui apenas para o financiamento do auxílio-maternidade e subsidia as Caixas Rurais e as contribuiçōes de estudantes e participantes do serviço militar obrigatório.

As contribuições para o conjunto das Caixas são formalmente paritárias ${ }^{81}$ - pagas 50\% pelo empregador e 50\% pelo trabalhador, com exceção das Caixas Rurais. São descontadas dos salários até um limite definido legalmente, que corresponde a $75 \%$ do salário de contribuição para o sistema de aposentadorias e é reajustado a cada ano.

Em 1997, a taxa média de contribuição do GKV foi de 13,4\%, sendo $6,7 \%$ destes pagos pelos empresários e 6,7\% pelos trabalhadores, descontados dos salários até o limite do salário de contribuiçāo. Este limite era de 6.150 marcos men-

80 Contribuir significa 'coopcrar com outrem nos meios para a realização de algo'. Tanto contribuem os trabalhadores uns com outros, como os empregadores com os empregados. 
sais (cerca de US $\$ 3.700)^{82}$ para a região ocidental e 5.325 marcos para a região oriental, valores acima dos quais, ao mesmo tcmpo, os assalariados são dispensados do asseguramento obrigatório. As taxas de contribuição têm aumentado gradualmente desde a década de 70 , motivando uma série de medidas de contenção. (vide tabela 6 ). ${ }^{83}$

Conforme o tipo de contribuinte, vigem regras específicas. Trabalhadores ativos e seus empregadores contribuem cada qual com a metade da taxa de contribuição. Os aposentados contribuem para o seguro-doença com uma taxa que corresponde à taxa média nacional do conjunto das Caixas e é paga $50 \%$ pelo aposentado e $50 \%$ pela previdência social. ${ }^{84}$ Para cálculo das contribuições dos aposentados, leva-se em conta o total da renda recebida até o limite de contribuição, incluindo-se outros tipos de pensão ou remuneração de trabalho (BMAS, 1994).

Para as Caixas Rurais, as contribuiçōes são feitas apenas pelos segurados, uma vez que se trata de pequenos proprietários. Estes pagam o total de suas contribuições e a dos familiares empregados. Para esse cálculo há definição legal de classes de contribuiçōes. A União financia parte das despesas com saúde das Caixas Rurais ${ }^{85}$ (BMAS, 1994). Para o cálculo das contribuições dos segurados voluntários - ativos e aposentados - e dos autônomos incluídos, é levado em conta o conjunto de suas rendas até o limite do salário de contribuiçăo obrigatória. Estipula-se também uma contribuição mínima mensal.

A definiçāo do valor das contribuiçōes é responsabilidade dos Conselhos de Administração de cada Caixa. Alteraçõcs das taxas de contribuição são decididas por consenso pelos representantes de empregadores e empregados integrantes destcs conselhos. Para entrar em vigor, a decisão deve scr homologada pelo órgão estatal de vigilância. Como será visto adiante, a autonomia das Caixas em relação à definição das taxas de contribuição foi reduzida nos anos 90 .

As taxas de contribuição são definidas pcla administração autônoma de cada uma das Caixas, de tal forma que as receitas de contribuição possam cobrir as despesas previstas. As Caixas são instituiçõcs não lucrativas e funcionam em sistema de cobertura dos gastos correntes. As contribuiçōes devem ser calculadas de modo que as receitas cubram as despesas e garantam rescrva definida legalmente.

82 O câmbio variou muito em 1997. Opta-se, neste trabalho, por uma taxa aproximada de 1,6 marcos por dólar (a variação foi até 1,8). Considerando as taxas médias de contribuição, a contribuição máxima de um trabalhador na região ocidental seria de aproximadamente USS 250 por mês.

83 O aumento mais expressivo ocorreu no início dos anos de 1970 por conta de ampliação da oferta de ações.

81 A partir de 1997, a taxa de contribuiçāo dos aposentados passou a ser a mesma que a dos outros segurados daquela Caixa por causa da plena vigência de compensação financeira da estrutura de riscos e liberdade de escolha das Caixas.

85 Em 1993, a Uniāo cobriu $51,3 \%$ dos gastos destes órgãos. 
Se, por um lado, aumentos de despesa implicam necessariamente a equivalente elevação das taxas de contribuição, por outro, os superávites acarretam a obrigatoriedade de reduçōes.

\section{Condicionantes de diferenças nas taxas de contribuição}

Uma das características do GKV é a existência de grande intervalo entre taxas de contribuição dos diversos órgāos provedores de seguro-doença. As taxas de contribuição são diferenciadas entre as Caixas $\mathrm{cm}$ decorrência da afiliação compulsória de grupos ocupacionais a tipos específicos de Caixas, o que cristalizou grupos de segurados com riscos distintos. A estrutura de riscos dos segurados é determinante de suas necessidades financeiras, uma vez que a grande maioria de ações e benefício a serem garantidos são definidos legalmente. Em geral, velhos utilizam mais do que jovens, mulheres mais do que homens, pessoas de baixa renda mais do que as de alta renda, aposentados mais do que outros grupos de segurados e doentes crônicos mais do que doentes agudos (SVR, 1987).

O valor das taxas de contribuição de uma Caixa é condicionado pelo nível de renda e depende da composição etária e por sexo, da morbidade, do número de dependentes e da conseqüente utilização diferenciada de seus segurados. As Caixas menores, com estrutura de riscos dos segurados menos favorável e localizadas em regiōes onde os salários são mais baixos, apresentam com freqüência taxas de contribuição mais elevadas do que outras, de clientela mais vantajosa. Desigualdades na utilização dos serviços por conta da estrutura de riscos e receitas mais baixas em razão dos menores salários obrigam as Caixas a estipular taxas de contribuição mais elevadas para poderem arcar com os gastos em saúde de seus associados, uma vez que o catálogo de serviços é semelhante. ${ }^{86}$

A influência de fatores de risco no valor das taxas de contribuiçāo de cada Caixa foi legalmente reconhecida nos anos 90 , sendo criado um mecanismo de compensação financeira da estrutura de riscos entre as Caixas, pela Lei da Estrutura de Saúde, em vigor desde $1993 .^{87}$

Esta foi uma das mais importantes medidas introduzidas no sentido de prevenir, ainda que não totalmente, a seleção de riscos. Semelhante mecanismo garante o não esfacelamento da solidariedade, conseqüência previsível da intro-

\footnotetext{
86 Como as Caixas năo podem solicitar falência, recorrem ao aumento das taxas de contribuição para cobrir as despesas das Caixas.

87 Este mecanismo será detalhado adiante na discussão das reformas.
} 
dução da competição entre as Caixas. Na compensação financeira da estrutura de riscos foram inscritos como fatores: o nível de renda, a cstrutura etária, a distribuição por sexo e o número de dependentes, bem como a proporção de aposentados já compensada anteriormente.

\section{Nível de renda}

Por sua centralidade no trabalho assalariado, as potencialidades de financiamento do seguro social têm relação direta com a situação do mercado de trabalho, o nível de emprego e o valor dos salários. As potencialidades financeiras de uma Caixa dependem imediatamente da inserção ocupacional e do nível dos salários de contribuição de seus membros. Isto é, quanto mais altos forem os salários de seus membros, mais elevado será o potencial financeiro de uma Caixa e, sob iguais condições de utilização, menores poderão ser suas taxas de contribuição.

Nas últimas décadas acentuaram-se as disparidades no potencial de receitas por tipo de Caixas em razão das diferenças de renda entre os segurados. ${ }^{88}$ São observadas expressivas diferenças entre a média dos salários de contribuição dos membros dos diversos tipos de Caixa e, para um mesmo tipo, entre as diversas regiōes. Naquelas economicamente mais fracas ou cuja cconomia passa por crise, a renda dos segurados é mais baixa e, por conseqüência, as taxas de contribuição são mais elevadas (Stegmüller, 1996a; Wynsong \& Abel,1990).

\section{Distribuição etária}

É reconhecido que, em geral, o estado de saúde de um indivíduo piora com a idade. Segundo os resultados do microcenso de $1995,12,3 \%$ da população entrevistada considerava-se impossibilitada do pleno exercício das atividades habituais. No grupo acima de 65 anos, entretanto, esta proporção duplicava-se, atingindo 25,4\% dos integrantes desta faixa etária (Hein, 1996).

A distribuição etária varia de forma marcante entre as Caixas. Algumas apresentam composiçāo etária muito mais favorável do que outras, o que implica diferenças em suas necessidades financeiras. ${ }^{89}$ A estrutura etária afeta o valor das taxas de contribuição não apenas diretamente em decorrência do

88 Enquanto a diferença na média dos salários de contribuição por membro entre as diversas Caixas era de $23 \%$, em 1970 , esta diferença elevara-se para $42 \%$, cm 1992 . É de 35.199 marcos a menor renda média por contribuinte por ano e de 50.515 marcos a maior renda média (Stegmüller, 1996: 90).

89. O grupo de contribuintes das Caixas Locais tem composição desfavorável quanto à renda - a média dos salários é mais baixa - e a estrutura etária é mais alta, com proporção maior de membros acima de 40 anos do que a média do conjunto das Caixas (Stegmüller, 1996:93s). 
risco de adoecer ou de portar doenças crônicas. Idades mais avançadas também significam usualmente rendas mais baixas, em especial, no caso de aposentados. A influência da proporção de aposentados entre os segurados de uma Caixa no nível de utilizaçāo e, em conseqüência, na determinaçāo de maiores gastos e, respectivamente, em taxas mais altas de contribuição, desde 1978, é compensada por meio de um mecanismo da equiparaçāo financeira deste peso entre as Caixas, incorporado em 1993 à compensação financeira de estrutura de riscos instituída.

\section{Distribuição por sexo}

Estudos relativos à utilização dos serviços de saúde de acordo com o sexo têm demonstrado que os gastos de saúde per capita das mulheres são mais elevados do que os dos homens. A maior utilização está ligada à morbidade condicionada pelo sexo e difere conforme a idade considerada na análise (Schneider, 1994). Além disso, as contribuiçōes femininas para o Seguro Social de Doença (GKV) são mais baixas, porque as mulheres contribuintes, de modo usual - porém, injusto -, recebem salários menores. Assim, elas contribuem com menores quantias, mas são responsáveis por gastos mais elevados do que os homens. Deste modo, a distribuição desigual de contribuintes homens e mulheres entre as Caixas provoca impacto no valor das taxas de contribuição, produzindo diferenciações.

A distribuição dos contribuintes por sexo entre as Caixas decorre da participação diferenciada de homens e mulheres no mercado de trabalho, que se reflete na estrutura do GKV, organizado tradicionalmente em diferentes tipos de órgãos relacionados à inserção ocupacional de seus membros. Em decorrência de particularidades culturais relacionadas à influência da igreja na conformação da proteção social, em defesa da família e, em especial, do papel da mulher como a mãe, a participação feminina no mercado de trabalho na Alemanha é baixa se comparada com os países nórdicos. ${ }^{90}$ Assim, além de uma maior prporção de homens entre os contribuintes, a aprticipação de mulheres entre as Caixas varia de forma expressiva. As Caixas Substitutas para Empregados sāo as únicas com maior proporção de contribuintes mulheres do que homens. Nas Caixas Substitutas para Operários e nas Caixas de Corporaçōes, a grande maioria (mais de $75 \%$ ) dos contribuintes é de homens. Na região oriental, a proporção de mulhcres contribuintes é maior do que na região ocidental."1

90 Em 1996, na Alemanha, 55\% das mulheres entre 15 e 64 anos eram ativas economicamente, enquanto na Dinamarca esta proporção era de 70\% (Der Spiegel, 16/1998).

91 Além disso, a distribuição das mulheres segundo a faixa etária também é dilerenciada. Nas Caixas Substitutas para Empregados, a proporção de mulheres até 30 anos é maior do que a média para as Caixas Locais. Esta faixa etária engloba, em geral, maior proporção de solteiras, por conseguinte, com menor número de dependentes. 


\section{Proporção de dependentes}

Em razāo de os familiares dependentes serem isentos de contribuição, cada um significa peso financeiro adicional para a Caixa, uma vez que se inclui um segurado sem o correspondente aporte financeiro. A proporção de dependentes no conjunto de segurados do GKV em 1997 era de 29\%, sendo mais baixa na região oriental (22\%) do que na ocidental (31\%), em particular, por conta da maior participaçāo de mulheres no mercado de trabalho e, conseqüentemente, da existência de maior número de mulheres contribuintes na região oriental.

As diferenças entre as Caixas em relação ao número de dependentes também são importantes. As Caixas de Mineiros e Rurais são as mais prejudicadas neste sentido. As Caixas Rurais têm 63 dependentes e as Caixas dos Mineiros 50 dependentes para cada 100 contribuintes (BMG, 1996).

A relação do número de dependentes também é diferenciada entre os segurados voluntários e os segurados obrigatórios. Na região ocidental, a proporção de dependentes entre os segurados voluntários é expressivamente maior para todas as Caixas, exceto para as Rurais. Isto mostra que há cálculo econômico na adesão das camadas de maior renda ao sistema solidário. Na ultrapassagem do limite de renda de asseguramento obrigatório, quando da escolha da permanência no seguro social ou da eleição de seguro privado, os contribuintes com dependentes optam por permanecer filiados ao GKV, aproveitando-se assim deste aspecto da solidariedade. $\mathrm{O}$ asseguramento privado implicaria o pagamento de prêmios individuais para cada um dos integrantes da família.

\section{Taxas de contribuição por tipo de Caixa}

Em virtude da existência destas diferenças na estrutura dos segurados, até recentemente, uma das características do GKV era a existência de grande intervalo de variação entre as taxas de contribuição das distintas Caixas. Esta é conseqüência importante da forma de organização do Seguro Social de Doença centrada no lugar ocupado pelo trabalhador no processo de produção.

Essas expressivas diferenças nas taxas de contribuição entre as Caixas contradizem o princípio da solidariedade, segundo o qual cada um deve contribuir proporcionalmente a sua renda. Segurados com igual renda, mas adscritos a diferentes Caixas contribuem com montantes díspares. Além disso, a diferenciação das taxas de contribuiçāo é o principal indicativo de que a solidariedade tradicionalmente nāo se exerce entre o conjunto de segurados, mas apenas no interior de cada grupo de segurados de uma Caixa. 
As diferenças nas taxas de contribuição entre as Caixas individuais foram sempre muito importantes. Desde os anos de 1970, a mais alta taxa de contribuição de uma Caixa é mais do que o dobro da mais baixa. Como se observa na figura abaixo, a maior taxa de contribuição correspondia, em 1975 , a 2,8 vezes a menor. Em 1993, esta relação ainda mantinha-se próxima ao dobro: a maior taxa de contribuição foi de $16,8 \%$, $\mathrm{c}$ a mais baixa de apenas $8,5 \%$. No interior de cada tipo específico de Caixa, as maiores diferenças encontram-se entre as Caixas de Empresas. Já as Caixas Substitutas para Empregados apresentam o menor intervalo de variação, pois têm adscrição nacional e, em geral, têm alto número de filiados.

Gráfico 1 - Mais alta e mais baixa taxa de contribuição por tipo de Caixa. Alemanha Ocidental - 1975 - 1993

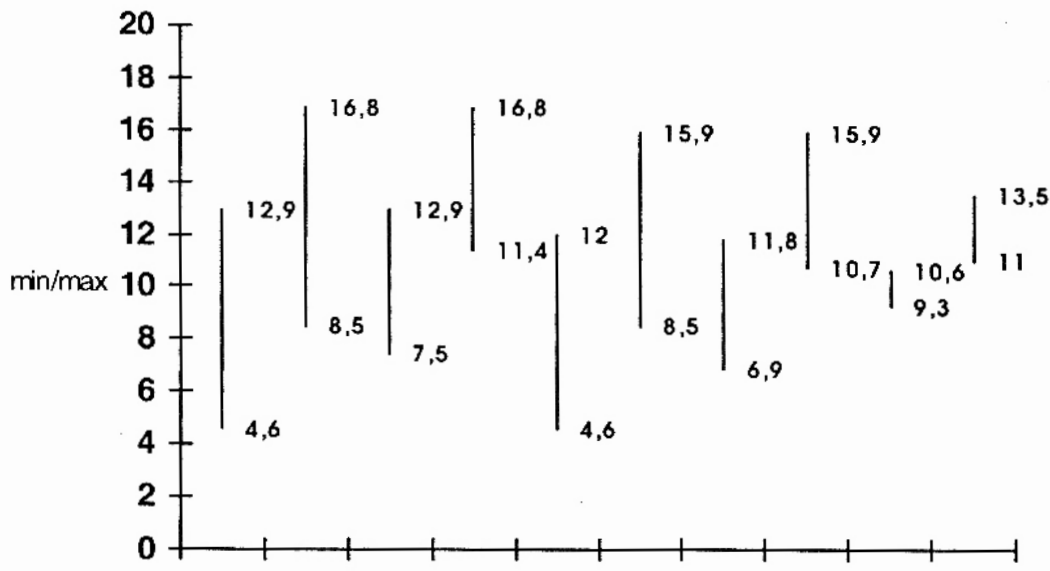

1975199319751993197519931975199319751993

Fonte: SVR, 1994:331; claboração própria.

As diferenças das taxas de contribuição médias anuais por tipos de Caixa são muito menores do que aquelas entre Caixas individuais demonstradas acima, mas nem por isso menos importantes. As Caixas de Empresas e as Caixas Substitutas para Operários apresentam taxas tradicionalmente mais baixas, como pode ser observado na tabela abaixo. Nos anos de 1970, as maiores diferenças das taxas médias de contribuição ocorriam entre as Caixas de 
Empresas e as Caixas Substitutas para Empregados, provavelmente por conta da oferta de benefícios adicionais por parte das últimas. Desde os anos 80 , as Caixas Locais apresentam invariavelmente as taxas médias de contribuiçāo mais elevadas, observando-se maior diferença entre suas taxas e as das Caixas Substitutas para Empregados.

A diferença das taxas médias de contribuição entre os diversos tipos de Caixas aumentou gradualmente a partir dos anos 80 , alcançando seu ápice no início dos anos de 1990, em decorrência da progressiva unificaçāo do catálogo e da manutenção de grupos de segurados fechados com cstrutura de riscos diferenciada.

Tabela 6 - Taxas de contribuição médias anuais por tipos de Caixas. Região Ocidental - 1970-1996

\begin{tabular}{rrrrrrrr}
\hline Ano & GKV * & Locais & Empresas & Corpor. & $\begin{array}{r}\text { Subst. } \\
\text { Operários }\end{array}$ & $\begin{array}{c}\text { Subst. } \\
\text { Empreg }\end{array}$ & $\begin{array}{c}\text { Dif.** } \\
>\mathrm{e}<\end{array}$ \\
\hline 1970 & 8,20 & 8,15 & 7,51 & 7,82 & 8,07 & 8,89 & 1,38 \\
1975 & 10,47 & 10,64 & 9,43 & 10,38 & 10,17 & 10,69 & 1,26 \\
1980 & 11,38 & 11,70 & 10,49 & 11,21 & 11,01 & 11,22 & 1,21 \\
1985 & 11,81 & 12,11 & 10,29 & 11,27 & 11,33 & 12,10 & 1,82 \\
1988 & 12,90 & 13,46 & 11,45 & 12,79 & 11,95 & 12,69 & 2,13 \\
1990 & 12,53 & 13,13 & 11,10 & 12,28 & 11,23 & 12,32 & 2,03 \\
1995 & 13,24 & 13,57 & 12,20 & 12,71 & 13,18 & 13,29 & 1,37 \\
1996 & 13,47 & 13,83 & 12,59 & 13,11 & 12,97 & 13,45 & 1,24 \\
\hline
\end{tabular}

* Taxas médias de contribuição do conjunto das Caixas, inclusive Caixa dos Minciros e Caixa dos Marítimos. **Diferenças cm númcro de pontos percentuais entre a maior e menor taxa de contribuição média anual.

Fonte: SVR, 1994:330; BMG, 1995b c 1997.

A partir de 1993, com a implementação da compensaçāo financeira da estrutura de riscos entre as Caixas houve sensível redução dessas diferenças. Este mecanismo promoveu lenta, porém constante, redução das diferenças das taxas de contribuição médias entre Caixas. ${ }^{92}$ É exatamente no sentido deste resultado de aproximação das taxas de contribuição que se pode afirmar que a Lei da Estrutura da Saúde reforçou a solidariedade ao estabelecer a compensação financeira de riscos. ${ }^{93}$

12 O intervalo de variação entre a maior e a menor taxa média de contribuição diminuiu de 2,36 para 1,16 pontos percentuais entre 1992 e 1997.

93 Mesmo com estas aproximaçōes, em janeiro de 1997 permaneciam importantes diferenças nass taxas de contribuição entre Caixas. Entre as Caixas Substiutas, as taxas de contribuição variavam entre 11,5 e 14 pontos percentuais. Para as Caixas Locais, a maior taxa era de 14,9\% e a menor, de $13 \%$ (Die BKK). 


\section{Administração Autônoma}

No seguro social, o Estado estipula as condiçōes gerais de funcionamento do sistema, mas não administra diretamente as entidades provedoras de seguro. As Caixas de Doença, assim como as instituiçōes dos outros ramos do seguro social, não são de competência imediata da administração estatal. Constituem instituições de direito público, rcguladas pelo Estado, cuja administração é de responsabilidade dos cmpregadores e trabalhadores. A administração das entidades provedoras de seguro social é, assim, autônoma.

As Caixas de Doença desfrutam de autonomia financeira e organizacional, estando subordinadas, porćm, à regulaçăo e vigilância estatais. A regulação é imprescindível para a garantia de princípios de justiça social. Desse modo, autonomia administrativa na área social significa liberdade de ação para a execuçāo de tarcfäs legalmente definidas.

Oficialmente, o princípio de 'administração autônoma' (Selbstvcrwaltung) ${ }^{94}$ proporcionaria a possibilidade de colaboração imediata dos participantes na conformaçâo e aperfeiçoamcnto do asseguramento $\mathrm{cm}$ caso de doença. Ademais, contribuiria para a promoção de parcerias sociais e da ordem social. Por meio da constituiçāo de órgãos de administração autônoma no seguro social, a competĉncia de condução seria transfcrida do Estado para os cnvolvidos (BMAS, 1994). ${ }^{95}$

A administração autônoma tem por base a concepção de que esta seria a forma de organização mais adequada para intermediar as necessidades dos endereçados dos benefícios sociais e expressar os interesses específicos dos grupos. Os instrumentos de legislação e controle de orçamento à disposição no sistema parlamentar nāo seriam suficientes para garantir a atençāo voltada aos interesses do cidadāo. Os órgãos da administração autônoma, com a participação direta dos envolvidos, estariam mais aptos a cumprir esta funçāo (Ferner, 1976).

Desde a criação do seguro social, as entidades provedoras são instituições separadas da administração estatal direta. O princípio de administração autônoma para a organização das entidades provedoras do Seguro Social de Doença partiu do modelo das associações cooperativas de auto-ajuda, existentes à época

94 Considero o termo administração autônoma mais adequado do que autogestāo para a tradução do conceito Selbstverwaltung, dado o conteúdo específico de autogestāo como controle e administraçăo da empresa por trabalhadores. Administração autônoma implica, além de autonomia administrativa, a constituição de entidades separadas do aparato estatal direto.

95 Para Waneck (1994), a forma de organização das Caixas não corresponderia, de fato, ao tipo de administração autônoma coopcrativa de segurados; seria muito mais uma administração estatal indireta, complementada por clementos de conduçấo cxterna por meio dos sindicatos e associações de empresários. 
de criaçāo do Seguro Social de Doença, foram organizadas pelos trabalhadores com a finalidade de prestar auxílio a seus membros em caso de doença. ${ }^{96}$

As regras para a administração autônoma, a composiçāo dos órgãos de representação, a forma de eleição e a amplitude da autonomia modificaram-se ao longo do tempo, mas a existência de instituiçōes separadas da administração estatal direta, com dirigentes escolhidos pelos pares, foi mantida, com exceção do período nazista.

Em 1933, com o nacional-socialismo - a ditadura nazista -, a administração autônoma foi abolida. As Caixas sofreram intervenção e seus dirigentes passaram a ser nomeados por órgãos governamentais. Criados para substituir os órgãos da administração autônoma, os conselhos consultivos com a participação de empregados e empregadores foram compostos por pessoas nomeadas e não eleitas, tendo pouca possibilidade de influência. Ao término da guerra, a administração autônoma foi restaurada na zona de ocupaçāo francesa em 1948 e restabelecida, apenas em 1951, nas zonas de ocupação inglesa e americana (Seffen, 1973).

Em termos institucionais, a administração autônoma significa a constituição das Caixas como entidades não lucrativas de direito público. Em termos funcionais, exprime internamente a independência administrativa - liberdade para elaboração do estatuto, do orçamento, contratação de pessoal etc. - e financeira, com a possibilidade de definição das taxas de contribuição. Externamente corresponde à independência na relação com os segurados, à possibilidade de negociação de contratos com os prestadores e ao controle dos serviços prestados.

Os órgãos de gestão das Caixas são, em geral, compostos de forma paritária, constituídos por representantes dos empresários e trabalhadores eleitos por seus pares a cada seis anos. ${ }^{97}$ Os órgãos de gestão das Caixas Substitutas săo compostos apenas por representantes dos segurados. Nas Caixas dos Mineiros, dois terços dos membros destes conselhos são representantes de trabalhadores, e um terço, de empresários. ${ }^{98}$

96 Esta tradição era tão forte que tal característica foi mantida mesmo no contexto em que foi criado o seguro estatal de saúde, o de Estado autoritário e de ausência de direitos políticos para os trabalhadores. A incorporação desta forma de organizaçāo foi também condição para a aprovação da proposta bismarckiana no Parlamento (Siegerisı, 1943).

97 É interessante observar aqui a diferença de paridade dos Conselhos de Administração das Caixas e os Conselhos de Saúde do SUS. No SUS, a paridade é entre usuários e prestadores de scrviços. Nas Caixas de Doença alemãs, há paridade de empregadores e trabalhadores contribuintes do sistema em igual proporçăo. Os representantes dos empresários não são os mesmos dos prestadores privados de saúde ou dos produtores de insumos. Seu interesse aí não é como empresário do setor, mas como patrão que controla a utilização das contribuições sociais que paga.

98 Estas diferenças decorrem da forma de instituição e evolução dos distintos tipos de Caixas. No caso das Substitutas, por serem sucessoras das Caixas independentes, foram organizadas e administradas pelos próprios trabalhadores e incorporadas posteriormente ao sistema. 
Até 1995, as Caixas eram administradas por uma Assembléia de Representantes e uma Direção, ambas formadas por representantes eleitos. Uma reestruturação da administraçāo autônoma, na tentativa de aumentar a compctência das instâncias representativas, foi definida pela Lei da Estrutura de Saúde.

A partir de 1996, esses dois órgāos foram substituídos por um Conselho de Gestão, com número menor de membros honorários eleitos e uma direção remunerada, composta por três membros, no máximo, e escolhida pelo Conselho a cada seis anos. O Conselho de Gestão elege, controla e fiscaliza a direção, assim como define estatuto, orçamento c taxas de contribuição.

Com tal mudança, os representantes de cmpregadorcs e trabalhadores eleitos passaram a ter maior possibilidade de interferência na condução das Caixas tanto na definição de uma política geral de atuação da Caixas, mais voltada aos interesses dos segurados, quanto no controle de sua execução pelos gerentes contratados. Buscou-se ainda promover maior renovação dos membros da direção, delimitando-se prazos de mandato. Após eleitos, muitos dirigentes permaneciam nos cargos até chegarem próximos à aposentadoria, tomando-se os mesmos quase que postos vitalícios (Am Orde, 1997b). ${ }^{99}$

Estas mudanças nos órgãos de administração das Caixas objetivavam, ao mesmo tcmpo, promover uma administração mais empresarial. Os dirigentes remuncrados também tiveram suas competências ampliadas, desfrutando de autonomia ${ }^{100}$ mais ampla.

Além da administração de cada Caixa, as Associaçōes de Caixas, as de Médicos Credenciados das Caixas e as conjuntas, formadas por prestadores e Caixas, integram a administração autônoma. Os médicos credenciados organizam-se por regiōes/estados e em nível federal. Outro dos órgãos da administração autônoma é a Comissāo Federal de Médicos e Caixas, responsável pela definição da forma e extensão da atenção médica ambulatorial e constituída, de modo paritário, por representantes das Associaçôes de Médicos Credenciados e das Associações de Caixas. ${ }^{101}$ Recentemente, em 1997, as atribuições destas comissões conjuntas foram ampliadas, podendo decidir a respeito de questôes referentes à atenção prestada também por outros profissionais.

99 Agradeço a Betina Am Orde, responsável pela área de política social da Central Sindical (DGB) pclas informaçöes prestadlas em entrevista realizada em Düsseldorf, na sede da DGB, cm maio de 1997, que me permitiram compreender melhor o funcionamento da administração autônoma.

100 As mudanças centralizaram as estruturas de administração ao reduzir o número de representantes e ampliar competências da direção remunerada.

(1) Outras comissões conjuntas são: de arbitragem, de admissão de médicos, de delinição da pontuação dos serviços prestados. Note-se que a paridade nestas comissöes é entre as Caixas provedoras de seguro (compradores de serviços) e os médicos credenciados na qualidade de prestadores de serviços. 
A autonomia da administraçāo está condicionada pela legislaçāo vigente, que define seu âmbito de ação, o catálogo de serviços e as condições para a criação de uma Caixa, além do que adscreve clientelas, obriga o asseguramento em geral e, no caso dos médicos, a afiliação compulsónia às associaçōes de médicos credenciados.

O princípio de autonomia administrativa não significa autonomia irrestrita das Caixas em suas políticas de gastos e financiamento, âmbitos que sāo legalmente regulados. O Estado define, no Livro da Legislação Social (Código Social), os espaços de atuação das Caixas. Estas têm autonomia administrativa financeira, inclusive para a definiçāo das taxas de contribuição, de gestão de pessoal e, por intermédio de suas associaçōes, de estabelecimento de contratos com as organizações dos prestadores, cujas condições são igualmente legisladas.

A administração autônoma, ainda que desfrute de certa independência, representa uma forma mediada de intervenção estatal. ${ }^{102}$ Tanto suas compctências como o grau de autonomia são definidos a cada momento pela legislação em vigor. ${ }^{103}$ Contudo, o GKV é um dos ramos do seguro social que apresentou tradicionalmente maior grau de autonomia (Seffen, 1973).

Por ter como um de seus princípios constitutivos a solidariedade, o catálogo de serviços do Seguro Social de Doença (GKV) como assinalado acima - é único e definido legalmente, com restrita possibilidade de oferta de serviços diferenciados pelas Caixas. A aparente restrição da liberdade de açāo das Caixas neste campo é resultado de um processo de redução de privilégios e de obtenção de maior eqüidade. A maior intervenção estatal possibilitou assim a passagem progressiva da definição dos dircitos segundo o mérito para uma definição conforme a necessidade.

A atuação das Caixas é vigiada pelo Estado que fiscaliza a observância do cumprimento das responsabilidades legalmente atribuídas por meio de órgãos dos Departamentos de Saúde ou do Trabalho e Ordem Social cm nível estadual e do Ministério da Saúde e do Departamento Federal de Seguros em nível federal.

\section{Eleições}

As eleições para o Conselho de Gestão das Caixas de Doença, bem como para os outros ramos do seguro social, são denominadas eleições sociais. Estas são livres e sccretas, sendo realizadas a cada seis anos. Scgurados e empregadores

102 A discussão sobre a medida da 'autonomia da administração autônoma' é recorrente. A questāo é se esta significaria renúncia de dominação do Estado - renúncia de exercício do poder - ou apenas forma mediada de gestăo cstatal.

103 A questão da contradição entre fóruns participativos ou corporativos e o Parlamento resolvese aqui pela definição, pelo Parlamento, não apenas das competências, mas do grau de autonomia dos órgãos de seguro social. É no Parlamento, em última instância, que as questöes são resolvidas. 
clegem seus representantes de forma separada com base em uma lista de candidatos. Eleitores são todos os contribuintes maiores de 16 anos, além dos que podem candidatar-se, aqueles que atingiram a maioridade.

A apresentação de candidatos pode ser feita tanto pelos sindicatos ${ }^{104}$ quanto por associações de trabalhadores, desde que os objetivos da organização não se restrinjam à participação neste tipo de eleição e que preencham determinadas condiçōes (BMAS, 1994). Estas associaçōes são, de algum modo, importantes apenas para as Caixas Substitutas, que têm em seu conselho somente representantes de segurados. Nas outras Caixas, as listas de candidatos representantes dos trabalhadores são apresentadas em geral pela Central Sindical DGB e compostas por representantes dos sindicatos-membros. Pelo lado dos empregadores, as associações de empresários e suas federações são responsáveis pela apresentação das listas de candidatos. ${ }^{105}$

Se apenas uma lista for apresentada ou o número de candidatos do conjunto de listas não ultrapassar o número de vagas, os integrantes das listas serão considerados eleitos, ou seja, não há eleições. Esta prática é bastante comum e leva parte dos segurados a desconhecer a existência de eleiçōes - apenas $40 \%$ destes sabem que são realizadas (Deutscher Bundestag, 1990b; Braun, 1992). Além disso, os eleitores têm pouca informação acerca da posição dos candidatos e votam comumente em listas com algum nome conhecido, dificultando a renovação. Desse modo, embora a estrutura das Caixas seja formalmente democrática, a participação dos segurados é baixa.

Em 1993, por exemplo, para um conjunto de cerca de 1.400 Caixas dos vários ramos do seguro social (doença, previdência e acidentes de trabalho) que deveriam realizar eleiçōes, 27 Caixas o fizeram e, em geral, as maiores. A participação, mesmo baixa, nāo foi menor que em anos anteriores, pois cerca de $40 \%$ dos eleitores cnviaram seu voto.

A divulgação das cleiçōes é julgada como insatisfatória pela própria Central Sindical DGB. Nos últimos anos, a Central Sindical DGB tem buscado divulgar as eleiçōes sociais e estimular a participação por meio de propaganda em rádio e por meio de cartazes. Os resultados, porém, continuaram pouco expressivos, o que tem levado a Central Sindical a repensar as formas de mobilizaçăo eleitoral (Am Orde, 1997b).

104 Membros da Dcutscher Gewerkschaftsbund-DGB, Deutsche Angestcllten Gewekschaft-DAG e Christlicher Gewerkschaftsbund-CGB.

10.5 Além das organizações, segurados e empresários podem apresentar 'listas livres', caso contem com a assinatura de certa proporção do número de segurados. Estas 'listas livres' obtiveram algum sucesso, nos últimos anos, em Caixas pequenas. 


\section{Droblemas da administração autônoma}

O princípio de administração autônoma dos órgāo provedores do Scguro Social apresenta alta aceitação, pois nenhum dos principais atores sociais setoriais questiona esta forma de organização. Mesmo assim, diversos problemas são apontados.

Com o crescimento das estruturas burocráticas das Caixas e a profissionalização de sua gerência - cujos cargos foram ocupados por administradores de empresas com experiência no setor privado e/ou por administradores de serviços de saúde - ocorreu um distanciamento da gestão das Caixas, por parte dos trabalhadores, paralelo ao enfraquecimento de seus representantes. Concomitante a isso, a autonomia das Caixas foi sendo restringida, tanto com o objetivo de aumentar a cqüidade na distribuição de benefícios, quanto, mais recentemente, com o intuito de contenção de gastos.

São considerados como principais problemas da administração autônoma: a moderada competência de ação das Caixas, o pouco interesse dos sindicatos pelas Caixas e a baixa legitimação democrática de seus órgāos de administração (Waneck, 1994; Reiners, 1989). Estas deficiências podem ser encadcadas. A relativa falta de poder das Caixas tem produzido desinteresse dos sindicatos, tornando pouco atraente o trabalho nos órgãos de administração, o que contribui, por sua vez, para a baixa competência das Caixas. Nestas condiçôes, as Caixas seriam, de fato, entidades administrativas e não organizaçōes políticas (Reiners, 1989).

O problema principal seria a falta de poder das Caixas. Estas careceriam de poder tanto externa como internamente. Externamente, em relação ao Estado e aos prestadores de serviços - por conta da composição múltipla do sistema que gera rivalidades entre os diferentes tipos de Caixas - , internamente, em decorrência da forma de organização dos órgãos de administração (Reincrs, 1989).

As Caixas, ainda que ocupem lugar importante na estrutura de poder setorial, afinal, financiam centenas de bilhões de marcos de açōes médico-sanitárias anuais, têm pouca força frente aos prestadores. Elas se gerem, mas não controlam o sistema de atenção médica, cuja gestão seria responsabilidade conjunta de Caixas e prestadores de serviços. Na prática, as Caixas garantem, na forma de contribuições, os meios financeiros necessários, ao passo que as associações de médicos, os hospitais e outros prestadores de serviços são responsáveis pelo tipo e qualidade da atenção médica ofcrtada.

A competência das Caixas na condução da prestação dos serviços é restrita. Na atenção hospitalar, as Caixas têm pouca possibilidade de intervenção no que se refere à distribuição dos investimentos no setor - a cargo dos governos estaduais - e são obrigadas a contratar todos os hospitais incluídos no plano estadual específico, em cuja elaboração participam de forma subordinada. Na atenção ambulatorial é apontada uma assimetria de poder entre médicos e Caixas que é desfavorável para as últimas. 
Embora as Associaçōes de Caixas negociem preços separadamente, estão proibidas de negociar contratos com grupos de médicos; são obrigadas a fazê-lo com as Associaçōes de Médicos das Caixas, as quais, ao mesmo tempo em que garantem a atenção, detêm o monopólio da atenção ambulatorial. No setor ambulatorial, a possibilidade de controle de qualidade dos serviços prestados é também baixa. Uma vez que lhes é vedado a administração de serviços próprios, as Caixas não têm controle da prestação dos serviços. Os médicos detêm total autonomia na decisão do tipo, qualidade e quantidade das ações prestadas (Wanek, 1994).

As Caixas apresentariam também deficiência de poder em relaçāo ao Estado. Esta crítica, formulada de modo mais enfático pelos liberais, é acompanhada de propostas de privatização no sentido da introduçāo de mecanismos de mercado no sistema. A regulação estatal, porém, é necessária à garantia da solidariedade e uniformidade de direitos ao interior do sistema. Para Reiners (1989), o problema da relação GKV-Estado estaria em que o Estado tem delegado tarefas ao seguro social para rcsolver seus próprios problemas financeiros; políticas de contenção têm limitado a autonomia das Caixas, obrigando-as a introduzirem restriçōes.

A administração autônoma também não é garantia de administração participativa ou democrática. Mesmo que, em seu conjunto, grande número de representantes faça parte dos órgāos de co-gestāo, ${ }^{106}$ é restrita a possibilidade de influência dos segurados na política das Caixas. A própria composição paritária dos órgãos de gestão impediria uma representatividade adequada da comunidade de segurados.

Setorcs de representantes de trabalhadores questionam a composição paritária. Em decorrência das dificuldades de acordo, boa parte dos trabalhadores com assento nos órgãos de representação defendem que a composição deveria ser alterada. Argumentam que os empregadores estão sobre-representados e que seus interesses são totalmente diversos daqueles dos segurados, pois não integram a comunidade de segurados (Braun, 1992). Todavia, a participação de cmpregadores nos órgãos de gestão seria a maneira de estes assumirem responsabilidades e de se interessarem por questōes mais práticas na área social. Seria consoante com uma 'economia social de mercado', referência dos conservadores ao modelo alemão (Seffen, 1973). A composição paritária expressaria, de forma clara, aquele compromisso entre classes que teria caracterizado a constituiçāo dos modernos welfare states.

Em épocas de expansāo, tais parcerias sociais tenderam a dar melhores resultados. Pela participação conjunta neste tipo de fórum - concomitante à participação em fóruns diretamente relacionados a conflitos capital-trabalho --, trabalhadores e empregadores debateram temas da área social e consensos foram produzidos. Em tempos de restriçōes aflora a oposição de interesses. Suas contradiçōes ficam evidentes, tornando precária a interlocuçāo entre os 'parceiros sociais' e emperrando a tomada de decisóes (Am Orde, 1997b).

106 Cerca de 15 mil em 1989 (Braun, 1989). 
A medida da autonomia da 'administração autônoma' é questão em reiterada discussão. A defesa de maior autonomia tem diferentes conteúdos. Para as Caixas, visa à expansāo de sua influência no próprio sistema de atençāo à saúde, possibilitando maior controle dos prestadores e maior liberdade para o estabelecimento de contratos - mais favorávcis às Caixas $\mathrm{e}$, supostamente, para os scgurados -; para os liberais, expressa desrcgulamentação $\mathrm{c}$ introdução de mecanismos de mercado.

Na reforma de 1996-1997, a coalizăo liberal-conscrvadora incorporou a reivindicação das Caixas por maior autonomia em seu discurso. Contudo, sob o mote 'precedência para a administração autônoma', regras unificadas de controle dos prestadores foram abolidas e restrições à autonomia das Caixas, no que diz respeito à definição das taxas de contribuição, introduzidas. $O$ governo socialdemocrata/verde, após 1998, de modo distinı, encaminhou medidas para o reforço da competência das Caixas em sua relação com os prestadores. 